E\&BWT

\author{
UCL SSEES \\ Centre for Comparative Economics
}

\title{
China and Russia: Institutional Coherence between the Banking Systems
}

\author{
Andrei Vernikov ${ }^{a}$ \\ ${ }^{a}$ National Research University Higher School of Economics (Moscow) and \\ Russian Academy of Sciences (RAS) - Institute of Economics (Moscow)
}

\section{Economics and Business Working Paper No.130 \\ September 2014}




\title{
China and Russia: Institutional coherence between the banking systems
}

\author{
Andrei Vernikov \\ National Research University Higher School of Economics (Moscow), and \\ Russian Academy of Sciences (RAS) - Institute of Economics (Moscow)
}

Email: $\underline{\text { avernikov@hse.ru }}$

This version: September 2014

\begin{abstract}
We use statistical data from 2000 to 2013 to compare the macro-level structure and the core institutions of the banking systems in China and Russia. Our main hypothesis is that, differences in the absolute size and socio-cultural features notwithstanding, these two systems are typologically similar. We consider the institutional structure, the market structure and concentration, the industrial policy of the government, and the banks' involvement in the financing of the non-financial economy. We find both similarities and differences, however in dynamics the trend towards convergence prevails. In both countries, we see a hierarchical multi-tier banking system headed by a few core state-controlled banks. These combine commercial activities with the activity of a development institution. Regardless of the nominal form of bank ownership, the government exerts influence on the lending decisions and market behavior of banks. We argue that the case of banking in China and Russia provides empirical proof to the macrosociological theory of institutional matrices. We refer in particular to the needed proportion between the dominant and complementary institutions. Whereas China has been carefully seeking a sustainable balance, Russia in the 1990s grossly overshot with liberalization and now reverts to the underlying long-term trend. China has currently become Russia's donor for institutional innovations in the credit system design.
\end{abstract}

Key words: China, Russia, banks, government, comparative institutional analysis, path dependence, embeddedness, institutional self-adjustment

JEL codes: G21, G28, H82, P34, P52 


\section{Contents}

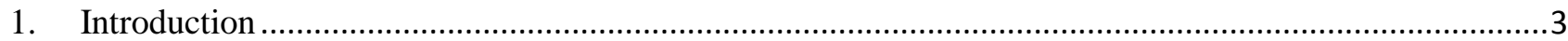

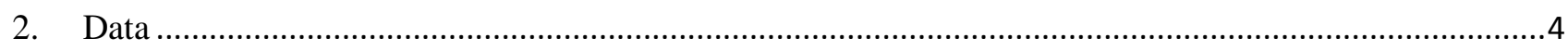

3. The size and the institutional structure of the banking system .........................................................

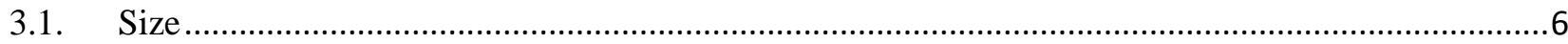

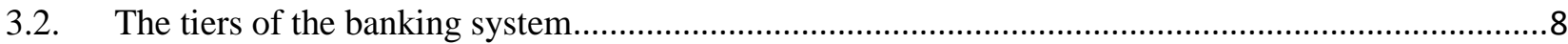

3.3. The market structure and concentration .......................................................................................

3.4. Banks' involvement in the financing of the real economy …......................................................15

3.5. Government interference into bank lending decisions .............................................................17

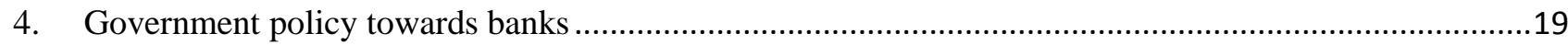

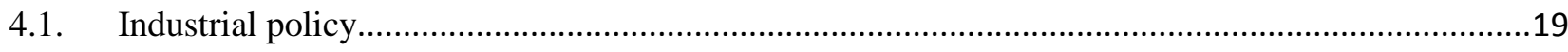

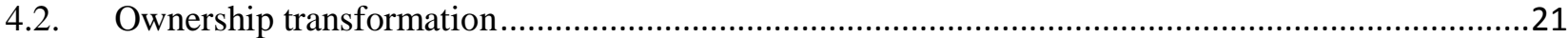

4.3. The treatment of foreign investment into bank equity .............................................................23

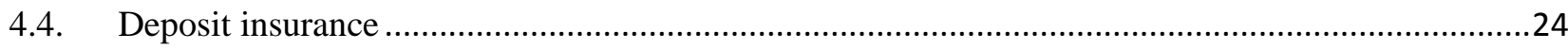

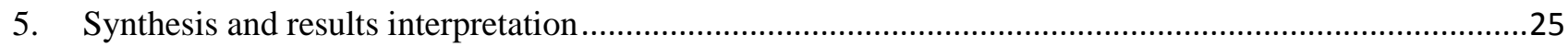

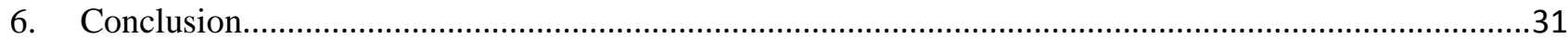

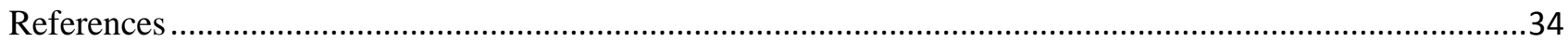

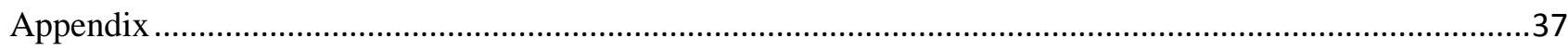




\section{Introduction}

Russian economic transformations have been compared to the reforms in Central and Eastern Europe (CEE) and in China. Most Russian authors assume that Russia embarked on the same path as CEE, whereas it should have gone «the Chinese way» to succeed in reforms at much lesser social cost [Polterovich, 2006].

As far as banking is concerned, single-country studies of China and Russia abound, but cross-country comparative studies are surprisingly scarce. Popov (1998) confronts the model of financial intermediation in Russia to other transition economies. Allen and Gale in their influential book (2000) focus primarily on developed market economies. Speranskaya compares the Russian banking model to the Chinese one in terms of the government presence and the involvement in the non-financial economy [Speranskaya, 2009]. She doubts that in the financial sphere the Russia patterns itself upon the Chinese variety of state capitalism, as it does in the industry.

The scarcity of comparative studies of China and Russia might result from the notion that, given its sheer size, the Chinese banking system, just like the country as a whole, is in a class of its own [Fungáčová, Korhonen, 2011, p.24]. The size of China does indeed impress, but any large economy, be it USA, Japan, India or Russia, might also pretend to be in a class of its own. Statistical indicators alone fail to explain the essential differences between China and developed market economies or essential similarities with a few Oriental countries as well as Russia. In this paper, we are interested in typological similarity that should be rather immune from differences in size.

Just 15 years ago, the evidence of the Russian banking, along with the liberal rhetoric, could feed the illusion of a market-based model based on competition and ownership pluralism. Since then a new kind of evidence challenges the conclusion about diverging models of banking in China and Russia. In particular, the government has increased its presence in the credit system as regulator, strategic planner and service provider. The authorities have pursued the industrial policy aimed at nurturing a few «national champions» [Vernikov, 2013]. Government bodies have interfered into the pricing of credit and household deposits. Some of the emerging institutional forms remind those in existence in the economy of the former Soviet Union. The new evidence suggests reverting to the issue raised by Speranskaya (2009).

Another source of motivation for this paper is the intention to quantify some of the elements of the theory of institutional matrices according to which China and Russia both belong to the same 
type of society [Kirdina, 2001; 2012; 2014]. The author has earlier tried to compare national banking systems, government banking and, more generally, institutional dynamics [Kirdina, Vernikov, 2013; Vernikov, 2009; 2012; 2014]. This time we look for structural and institutional coherence between commercial banks in China and Russia. Our method is morphological in the sense that we study the form and the specific structural features of organisms in search for a relationship between them. The research covers mainly the period between 2000 and 2013. Our basic hypothesis is three-fold: (a) the Russian banking system is typologically more coherent with China's rather than those in CEE transition economies; (b) the two national models of banking tend to converge, as their differences get eroded or weakened, while their similarities grow; (c) the Russian banking system is importing institutions and institutional forms from China.

The next section of the paper describes our data. Section 3 compares the institutional structure of the banking industry in China and Russia. Section 4 focuses on the government's industrial policy towards commercial banks. Section 5 summarizes preliminary findings of the previous sections and tries to interpret them. Section 6 concludes.

\section{Data}

We focus on the population of commercial banks in China and Russia. This leaves development banks and non-banking financial institutions of both countries beyond the scope ${ }^{1}$. In Russia the commercial banks are those reporting to the CBR and included in national banking statistics. As for China, we stick to the official definition of commercial banks that includes five types of financial intermediaries [CBRC, 2013, p.161], with the exception of adding here the Postal Savings Bank of China, or $P S B C^{2}$.

We rely upon data published by statistical offices and bank supervisors in China and Russia (China Banking Regulatory Commission or CBRC, and Central Bank of Russia, respectively), as well as web sites of the leading banks, the Bankscope database from Bureau van Dijk, The Banker

\footnotetext{
${ }^{1}$ Both countries have development banks (China Development Bank and Vneshekonombank). China also has «policy banks» (Export-Import Bank of China and Agricultural Development Bank of China). Vneshekonombank controls Russian commercial banks Roseximbank, MSP-bank, Globex and Svyaz-bank.

${ }^{2}$ PSBC is one of China's largest financial institutions with a vast branch network. CBRC Annual Report does not treat $P S B C$ as a commercial bank. We add $P S B C$ to the list of commercial banks for the sake of data compatibility with Russia where large state-controlled banks (Sberbank and Rosselkhozbank) perform similar functions in the rural areas.
} 
journal, RIA-Rating and RBK agencies, and international financial institutions (IMF and World Bank). Whenever possible we use relative indicators instead of absolute amounts in order to mitigate the difference in size between China and Russia.

Chinese bank data scarcity was the main obstacle to our research. The key official publication, CBRC Annual Report, is available in English after 2006 only, allowing building datasets of main aggregates since 2003. During this short period the bank classification and grouping have changed more than once; entire types of financial intermediaries have either emerged or disappeared (e.g., rural commercial banks and urban credit cooperatives). Data for selected years might be inconsistent. CBRC Annual reports contain no data on individual banks, even the largest ones. Only those few Chinese banks with a listing in the stock exchange disclose financial reports in English. The number of observations averaging less than one observation per bank per year does not suffice for statistical and econometric analysis, so one has to use aggregate data for selected categories of Chinese banks.

The statistics of international institutions such as IMF and the World Bank consist of data furnished by the national statistical agencies and therefore cannot be more complete or reliable than the original source.

Since 2007 the balance sheets of Chinese banks are disclosed in line with IFRS on a consolidated basis, i.e. jointly with overseas branches and subsidiaries. It overstates the scale of business in the mainland China and creates an upward bias for the market share of the core statecontrolled banks that have spread overseas. For the Russian banks we avoid this bias by looking at unconsolidated financial reporting.

Chinese banks keep off their balance sheets and do not disclose a substantial part of their operations, such as asset management trusts, wealth management products for high-net-worth individuals, or lending to real estate and commercial development [Wall Street Journal, 10.09.2013]. Official data available to researchers might reflect just one part of the reality but not the entire amount of a bank's assets and liabilities. 


\section{The size and the institutional structure of the banking system}

\section{1. $\quad$ Size}

Both countries have developed a bank-based financial system. Commercial banks prevail over other types of financial intermediaries. In China they control 78.5\% of total assets and $75.9 \%$ of all employees of financial institutions. In Russia commercial banks own over 90\% of all assets of financial institutions (calculated from CBRC and CBR data). As is typical for the German-Japanese model of financial intermediation [Popov, 1999], bank loans are the main source of financing for the non-financial sectors of the economy in China and Russia. Contrary to that model, however, banks do not own major industrial enterprises in either of the two countries. Banks might be losing market share to shadow banking institutions in China. By 2012, nearly one-half of the financial intermediation was taking place outside the formal banking sector, as compared to just $10 \%$ in the early 2000s [Liao, Tapsoba, 2014, p.3]. There are altogether 3,949 financial intermediaries in China, of which commercial banks make up only $1 / 6$.

China is ahead of Russia in terms of financial depth. The gap has shrunk in the proportion between bank deposits and GDP, but the correlation of deposit money bank assets to GDP in China still well exceeds that in Russia (Fig.1 and Annex 1). The assets to GDP indicator allows for various interpretations. On the one hand, it denotes the yet underutilized potential for bank lending to the economy in Russia. On the other hand, it reflects the credit boom that took place in China and the blowing of speculative bubbles, especially in real estate. The level of corporate indebtedness at 105.4\% of GDP in China is high and constitutes a systemic risk [PWC, 2012, p.36]. Chinese banks are hostage to the situation where continuing the credit expansion at the same pace as before is unsustainable, but halting it is politically unacceptable and would deteriorate financial indicators. Credit quality in China is another concern. Officially, the share of non-performing loans in the portfolios of Chinese banks is just around 1\%. Independent sources are more pessimistic. In 2012, the experts of Credit Suisse suggested the true number might be in the range between $8 \%$ and $12 \%$ [Cooper, 2012].

The behavior of the bank loan-to-deposits ratio (Fig.1-c) suggests that the Chinese banking industry might be moving from its initially risky profile towards more sustainable levels, while the Russian banks have been learning how to use the deposit base more efficiently (that particularly refers to Sberbank, the largest deposit-taker in the country). 


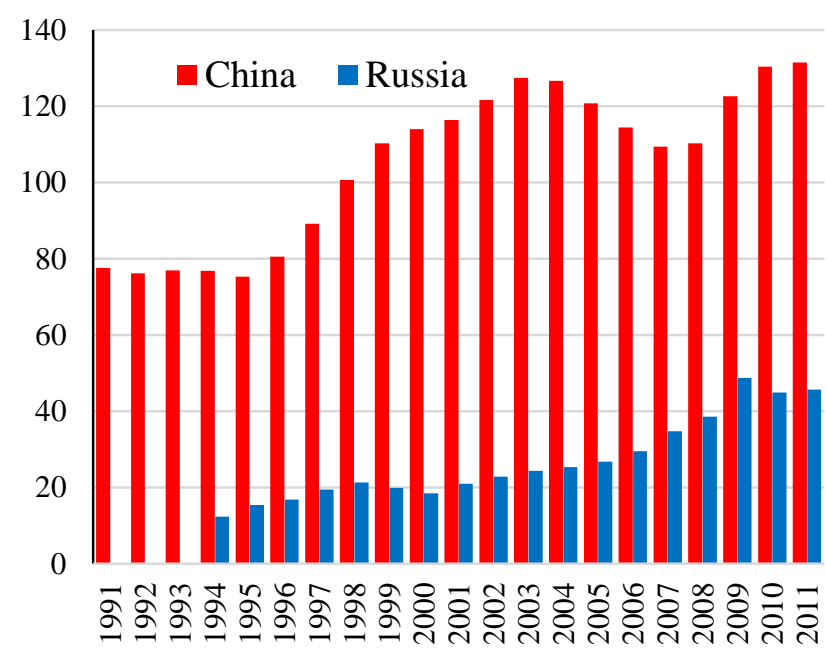

(a) deposit money bank assets / GDP, \%

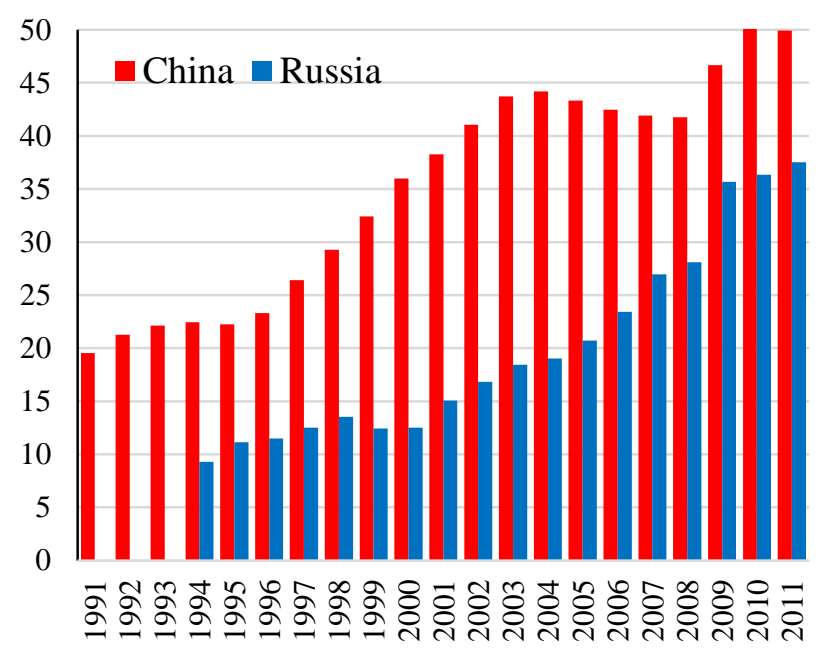

(b) bank deposits / GDP, \%

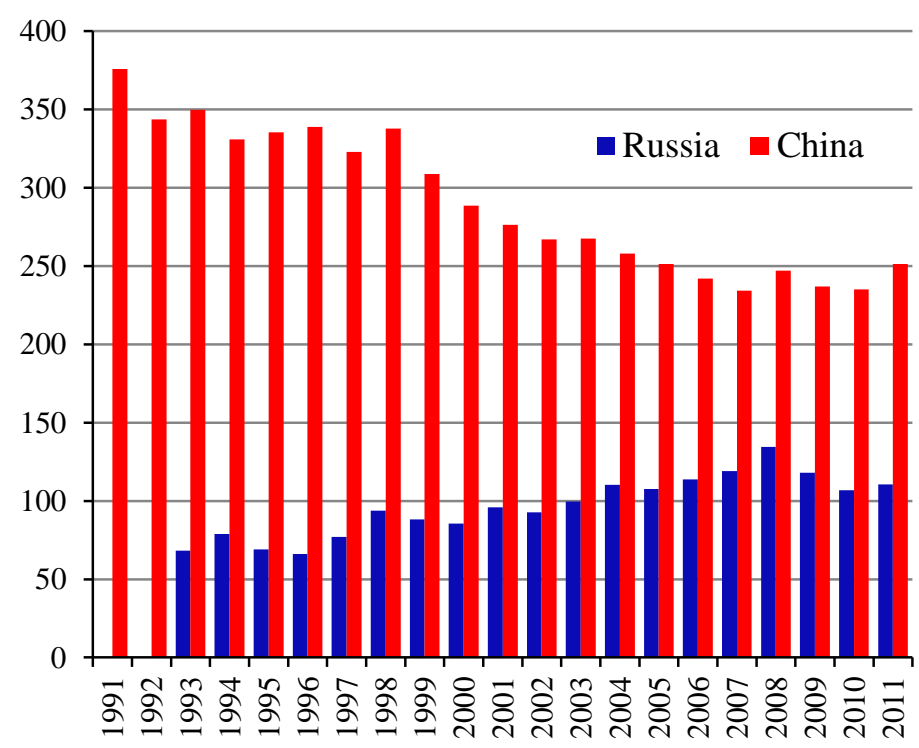

(c) bank credit to bank deposits, \%

Source: Financial Development and Structure Dataset (updated Nov. 2013). The World Bank, Washington DC

Fig. 1. Financial depth in China and Russia

The number of active banks is growing in China and falling in Russia, having reached 829 and $673^{3}$, respectively, by the end of 2013 (Fig. 2).

${ }^{3}$ The IMF database (Annex 3) quotes what we believe to be a low number of 203 commercial banks in China by 31.12.2012 [IMF, 2014b]. The IMF provides no comments explaining its discrepancy with CBRC data. We give credit to the latter. 


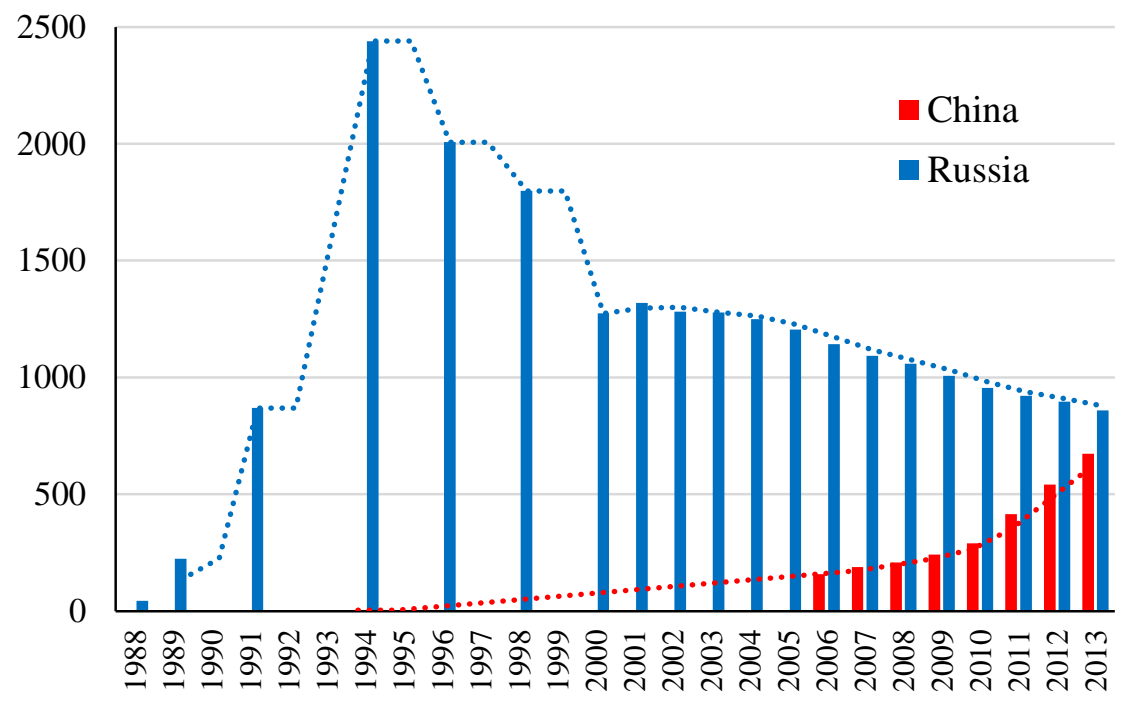

Sources: CBRC 2014 Annual Report, China Banking Regulatory Commission, Beijing, 2014, p.137; CBR

Fig. 2. The number of commercial banks, year-end

From the viewpoint of bank penetration and access to banking services, what matters is not the number of banks as legal entities but rather the overall number of banking entities and offices in absolute and relative terms. At the same time, the number of banking entities (bank branches, subbranches and other types of offices) keeps growing in both countries. It now exceeds 85,000 in China and 45,000 in Russia [CBR, 2014, p.13; IMF, 2014b]. The IMF database puts the total number of bank offices at 85,358 in China and 45,603 in Russia (Fig.2). Population density is higher in China, which explains why China has 9 bank offices per 1,000 km2 of territory as compared to less than 3 bank offices in Russia. Conversely, Russia exceeds China by the order of five in terms of bank offices per 100,000 adults, 38.2 and 7.7, respectively. A similar proportion describes the number of ATMs that complement bank branches. China has more ATMs per $1,000 \mathrm{~km} 2$ of territory and fewer ATMs per 100,000 adults (Annex 3). Overall, the geographical outreach of commercial banks in China and Russia is more or less comparable.

\subsection{The tiers of the banking system}

A two-tier banking system separating the central bank from all other banks has become an international benchmark and standard. In China, the People's Bank (PBC) kept mainly with macroeconomic monetary policy functions while bank supervision and regulation went to a specialized agency, the CBRC. In Russia, by contrast, the CBR is the supreme and sole regulator of 
the financial industry. In Russia all commercial banks are nominally equal as the banking law does not differentiate among them. In China the law on commercial banks establishes 3 different tiers in terms of minimum charter capital: RMB 50 million for a rural commercial bank, RMB 100 million for a city commercial bank, and RMB 1 billion for a «national commercial bank» [Law of the People's Republic of China on Commercial Banks, 2003, art.13]. In fact, both countries have a complex multi-tier banking system that is designed hierarchically. Differences between the tiers are essential and not merely numerical. Each tier embraces banks of a certain type that have different scope of business and client base and play a different role in the transmission mechanism of the monetary policy.

In China there are 5 «large commercial banks» (the core state-controlled banks), 12 «jointstock commercial banks», 145 city commercial banks, 468 rural commercial banks, 42 foreigncontrolled financial institutions [CBRC, 2014, p.137] and the Postal Savings Bank of China (Annex 2). One can distinguish three main tiers of the banking system, namely the core state-controlled institutions («large commercial banks»), joint-stock commercial banks of a national scale, and all other commercial banks - see Fig.3

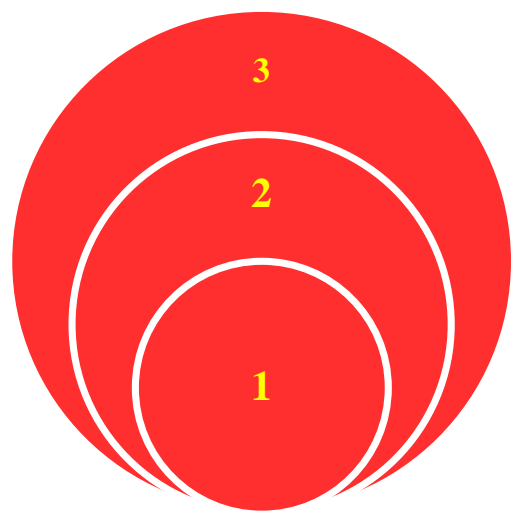

China

1. large commercial banks (5)

2. joint stock commercial banks (12)

3. City commercial banks (145); rural commercial banks (468); foreign financial institutions (42).

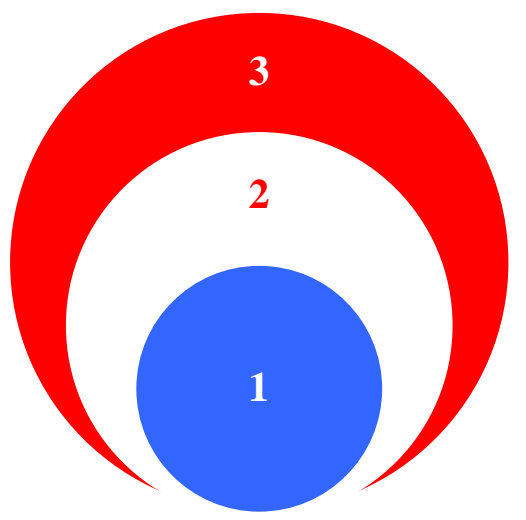

\section{Russia}

1. the core state-controlled banks (3)

2. other systemically important banks $(\sim 30)$ and «second-tier» banks ( 150)

3. all other banks $(\sim 650)$

\section{Fig. 3. Banking system design}

A «large commercial bank» has on average 12.7 times more employees and 6.1 times more assets than an average joint-stock commercial bank. In their turn, the joint-stock commercial banks exceed 
by an order of magnitude the size of the remaining commercial banks (Annex 4). Stratification implies that only large banking entities operate nation-wide, whereas many of the urban and particularly rural commercial banks operate within the boundaries of their home city (district, province). City commercial banks and rural commercial banks are hierarchically unrelated, so we place them in the same tier of the banking system regardless of the scale of their business.

A People's Bank of China publication suggests a somewhat different tiering of the system consisting of five levels: (1) Chinese-funded large-sized national banks (assets over RMB 2 trillion), (2) Chinese-funded small- and medium-sized national banks (assets under RMB 2 trillion, operate in various provinces), (3) Chinese-funded small- and medium-sized local banks (assets under RMB 2 trillion, operate within one province only), (4) small-sized rural financial institutions (rural commercial banks, rural cooperative banks and rural credit cooperatives), and (5) foreign-funded financial institutions [PBC, 2014, p.3]. The logic of the stratification remains the same.

In Russia, the largest state-controlled banks have emerged from the general population of commercial banks to constitute a separate tier of the banking system [Vernikov, 2014]. On average they have assets exceeding an average of the top- 20 non-state-controlled banks by an order of 12.4 times (author's calculation), which is similar to the gap between the two leading tiers in China. The gap between this tier and the next one (all other banks less 23 leading ones) is 38 -fold. The CBR as the top regulator admits the heterogeneity of the banking system by focusing on nearly 200 institutions of the «second circuit of banking supervision», of which some will be recognized as SIFIs (systemically important financial institutions) in line with BCBS recommendations.

For many years Russian experts have been debating the rationale for introducing additional types of banking licenses in order to legalize other types of banking entities such as regional banks that would be permitted to operate within a given territory while facing less stringent capital adequacy requirements. We find it likely that under the pressure from Basel-III capital requirements the Russian banking system may migrate towards the Chinese model with its multiple types of financial intermediaries. While this is not the case and there is no legal ground for a formal stratification of the population of banks, the CBR and other executive authorities act on ad hoc basis and establish minimal criteria of bank access to certain types of business. These criteria relate to a bank's equity, assets, years in existence, creditworthiness rating, ownership form, etc. In the spring of 2014, minimal size requirement was imposed on banks servicing the leading state-owned 
companies. Subsequently the CBR published a list of 35 banks that will be authorized for deposit of pension savings and housing savings of the military [http://www.banki.ru/ 01.07.2014].

\subsection{The market structure and concentration}

Market structure by the form of ownership denotes the lead of the public sector. Official statistics of China and Russia only covers one part of the public sector, so identifying state-controlled banks requires a separate study [Vernikov, 2009; 2012]. In China, absolute majority of joint stock, city and rural commercial banks were set up by state agencies and enterprises and funded by public capital. They remain closely related to the authorities, but it is hard to calculate an exact share of public ownership due to unclear ownership structure of bank shareholders. In Russia the market share of state-controlled banks comes close to $60 \%$ (Fig.4). This share shrank to about one-third of total bank assets during 1991 through 1998, but after the financial crisis of 1998 it resumed growth. China did not experience such a dramatic ownership transformation.

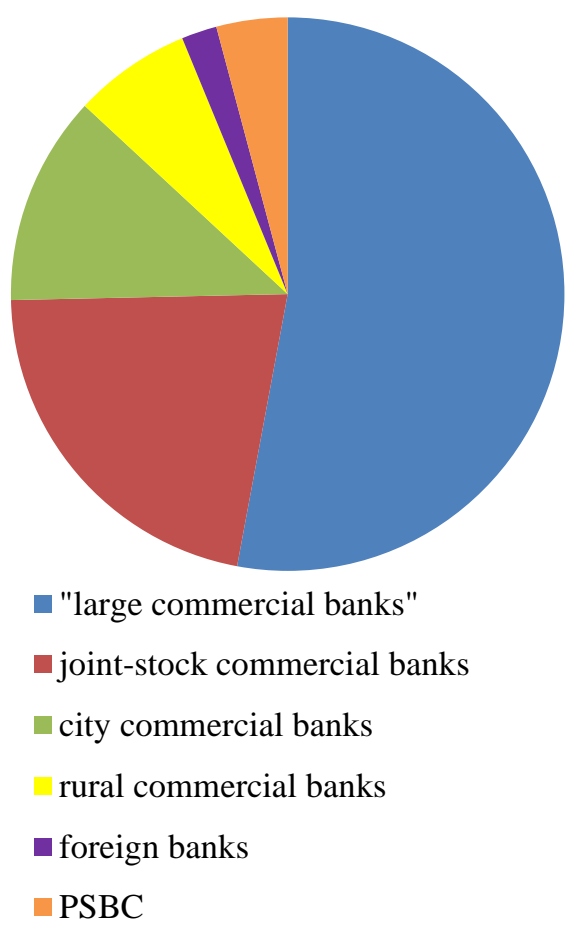

(a) China

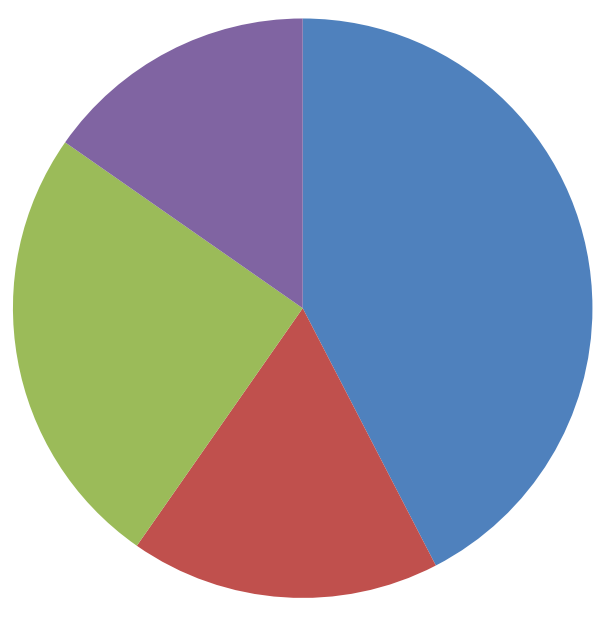

- largest state-controlled banks

other state-controlled banks

other banks

foreign-controlled banks

(b) Russia

Source: author's calculation based on data from: CBRC 2013 Annual Report, Beijing, 2014; The Banker, July 2014; CBR; RIA-Rating (http://riarating.ru/)

Fig. 4. Market structure in China and Russia (end-2013, percentage of commercial bank total assets) 
A few largest state-controlled banks constitute the core of the credit system in China and Russia. The market share of China's 5 «large commercial banks» has been on a gradual decline throughout the past years and dropped to 53\% of total commercial banking assets and 63\% of employees (Fig.5 and Annexes 2 and 5). It can produce an illusion of state withdrawal or divestment from the banking industry, which is not the case because «large commercial banks» keep growing. In Russia, the system of state-owned specialized banks (spetsbanki) that collapsed in the 1990s was succeeded after 1998 by a new generation of core state-controlled banks. The combined market share of Sberbank, VTB and Rosselkhozbank reached 42\%. The linear trend lines for both countries on Fig.5 might cross at some point near $50 \%$ of total assets and then converge.

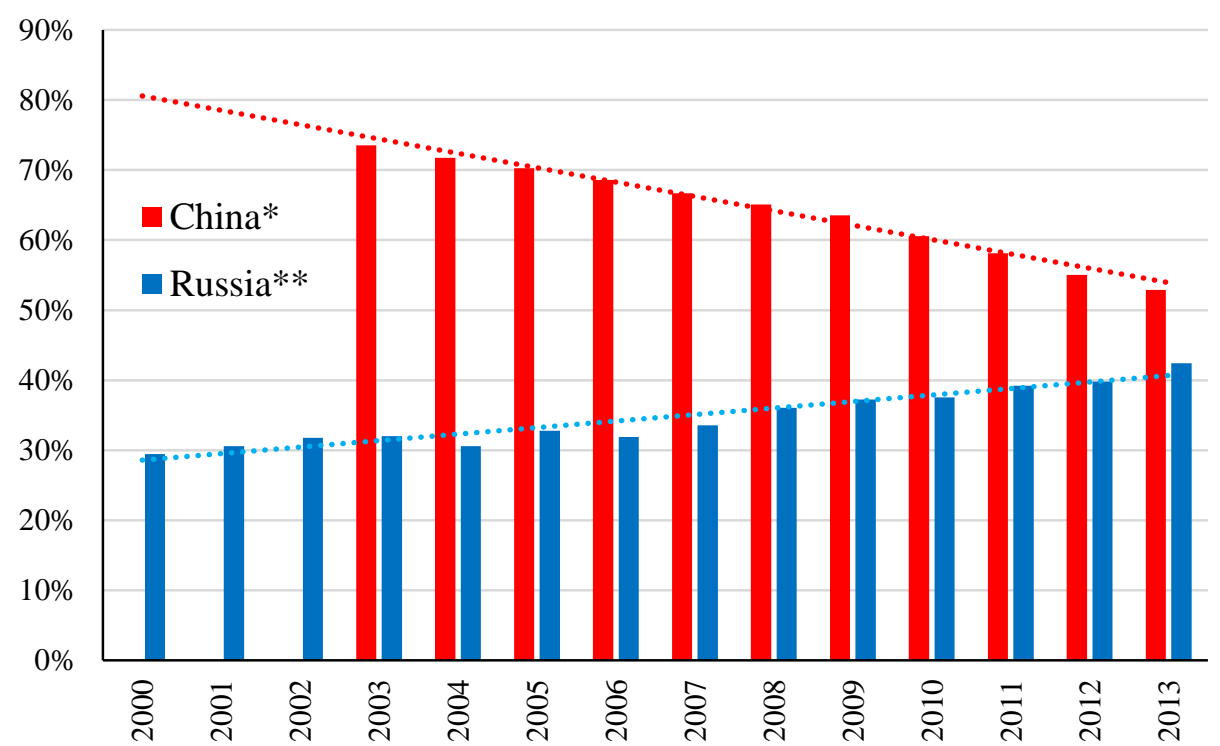

* Industrial and Commercial Bank of China, Agricultural Bank of China, Bank of China, China Construction Bank, and Bank of Communications. ** Sberbank of Russia, Bank VTB, and Rosselkhozbank, excluding subsidiaries thereof.

Source: author's calculation based upon data from: Annual Report 2013, China Banking Regulatory Commission, Beijing: 2014; The Banker, July 2014; CBR; RIA-Rating (http://riarating.ru/)

Fig. 5. Market shares of the core state-controlled banks (\% of commercial bank total assets)

The nominal share of state ownership explains some developments in the banking sector of China and Russia, but not all of them. The state has many tools, other than direct equity participation, to influence banks and companies. It can employ public procurement, liquidity allocation, access to national projects, and award of service contracts for public sector entities. Nominally private or foreign banks can be encouraged to act in concert with the government bodies or selected clans of civil servants. There are also opposite examples, of nominally state-owned banks that fall under the 
control of their managers and other insiders and change the operational regime (e.g., Bank Moskvy prior to its takeover by VTB). Identification and formalization of additional criteria of control could produce a more accurate industry structure by the form of ownership, but it remains a research task for the future.

Computation of the market share belonging to domestic private capital depends on the definition. In Russia it can be estimated within the range of $25 \%$ and $31 \%$. In China, it hardly exceeds $3 \%$. Official Chinese sources have mentioned a $12 \%$ share of private capital in banking, but it includes primarily the minority participations in the equity of large banks without access to control. Only Minsheng Bank is regarded fully private. In March 2014 the authorities announced an experiment aimed to produce five banks fully owned by private industrial companies [Financial Times 11.03.2014].

The market share of foreign-controlled banks in China has stabilized at about $2 \%$, including foreign bank branches and the locally incorporated banks with foreign equity. In Russia, the corresponding indicator reached its peak of almost 19\% in 2008 and then went into a slow decline to $15.3 \%$ in 2014.

The concentration in the banking industry of China and Russia is comparable and average by international standards. China does not put forward one prominent leader à la Sberbank of Russia. In terms of the Top-3 banks, the level of concentration is very similar.

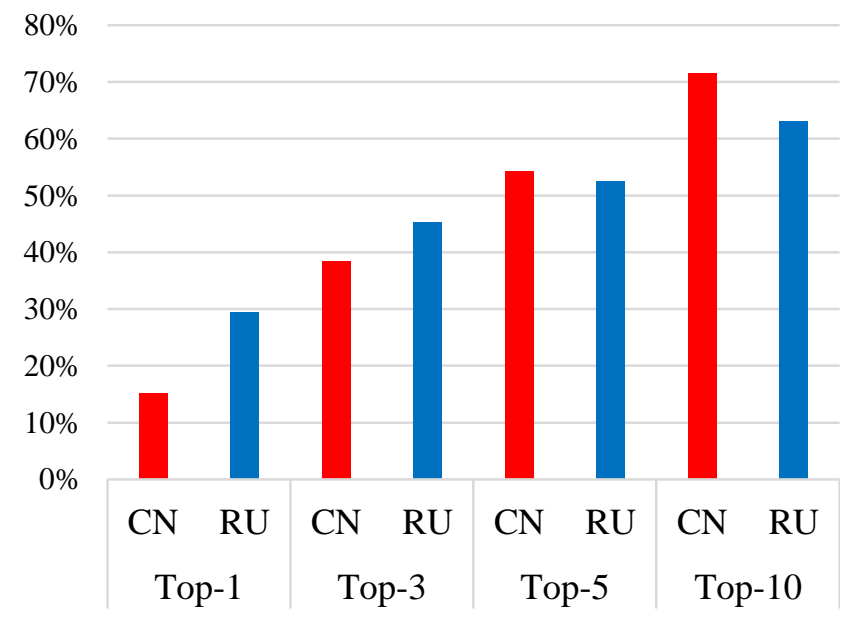

Source: author's calculation based upon data from: CBRC 2013 Annual Report, China Banking Regulatory Commission, Beijing: 2014; The Banker, July 2014; CBR; RIA-Rating (http://riarating.ru/)

Fig. 6. Commercial bank concentration (2013, percentage of total assets)

In terms of the Top-10 banks, China leads with $78 \%$ as opposed to $63 \%$ of total banking assets in 
Russia (Fig.6). Concentration jumps to a much higher level if one adds up the individual market shares of state-controlled banks. Those banks are ultimately controlled by the same party and can therefore be treated as a group of related parties whose individual indicators require consolidation according to the IFRS [Vernikov, 2013].

As has been already established by empirical research of national banking systems, the level of concentration is an inaccurate proxy for the intensity of competition, and competition is related to bank efficiency and sustainability in a non-linear way. The use of non-structural methods of competition research in our case is impaired by scarcity of Chinese bank-level data. A multi-tier structure of the banking system in both our countries implies strong market segmentation, so the absolute majority of banks compete locally rather than nationally.

Earlier papers on comparative efficiency of banks in transition predicted the lowest efficiency of state-owned banks in CEE countries [Bonin, Hasan, Wachtel, 2005]. Until recently, the studies of Chinese and Russian banks have been yielding similar outcomes. Berger, Hasan and Zhou argue that in 1994-2003 foreign banks were more efficient than large state-controlled banks in China, but a foreign equity stake, albeit minority one, increases a bank's efficiency [Berger, Hasan, Zhou, 2009]. Recent research admits the possibility for the state-controlled «national champions» to display financial efficiency not inferior than that of other types of market participants [Karas, Schoors, Weill, 2010; Fungáčová, Pessarossi, Weill, 2012; Vernikov, 2014]. Annex 6 cites the World Bank data on bank efficiency in Russia and China. It is hard to interpret the wide gap between the indicators of bank overhead costs to total assets or the cost to income ratio. The net interest margin appears narrower in China (2.9\%) than in Russia (4\%).

The main factors in charge of this mismatch are the directed lending and price controls. Each government, but especially the Chinese one, indicates to the core banks the desirable volumes and directions of lending and the desirable interest rates. It impairs the reliability of bank financial indicators such as interest margin and interest revenue, profit and return on equity. It also affects the empirical results that from time to time look unconventional, e.g. that in China competition has no effect on bank efficiency [Fungáčová, Pessarossi, Weill, 2012]; that state-controlled banks have lesser market power in Russia than domestic private and foreign-owned banks [Fungáčová, Solanko, Weill, 2010] or receive a narrower interest margin [Fungáčová, Poghosyan, 2011].

The form of ownership does not necessarily pre-determine banks' performance. Their 
business models, risk management policy, pricing policy, compensation policy are shaped by the market environment. If private initiative and free competition prevail, then state-controlled banks can borrow one of the behavior patterns of their main peers. Such a pattern might well be destructive. Prior to the 1998 crisis in Russia, the government-owned banks acted like their private peers in the sense that they speculated with government securities and foreign currencies and refrained from lending to the national economy.

\subsection{Banks' involvement in the financing of the real economy}

The main point of difference between China and Russia that Speranskaya (2009) emphasizes is the functional role of banks in the economy, their relevance and the lending decisions criteria. We compute that the share of domestic bank loans in the total fixed assets investment of non-financial companies is between $13 \%$ and $15 \%$ in China and $7 \%$ and $8 \%$ in Russia; the gap tends to shrink (Fig.7-a). Domestic bank loans constitute an essential, but not a prevailing, part of all external sources of investment into fixed assets, their share varying from $40 \%$ in China and $14 \%-16 \%$ in Russia $^{4}$ (Fig.7-b and Annex 7).

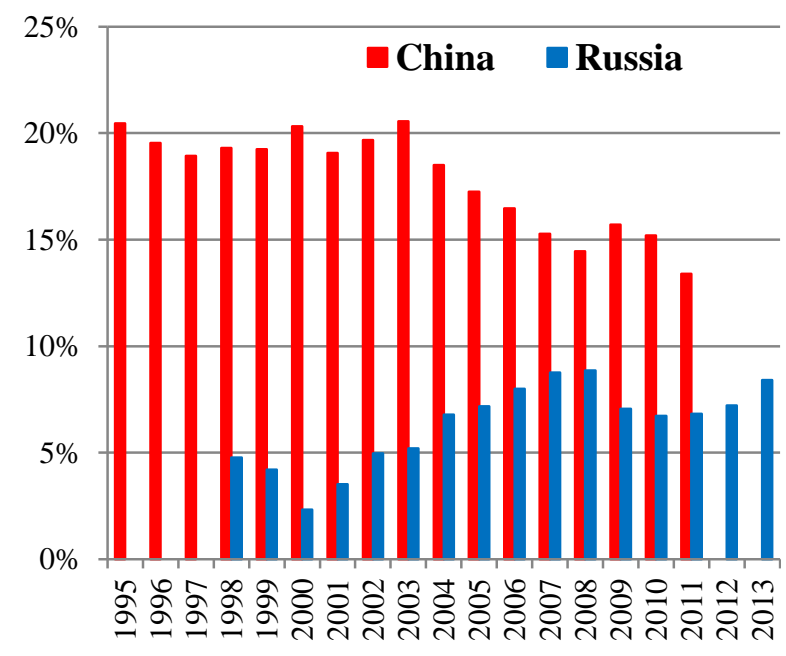

(a) The share of domestic bank loans in total investment into fixed assets

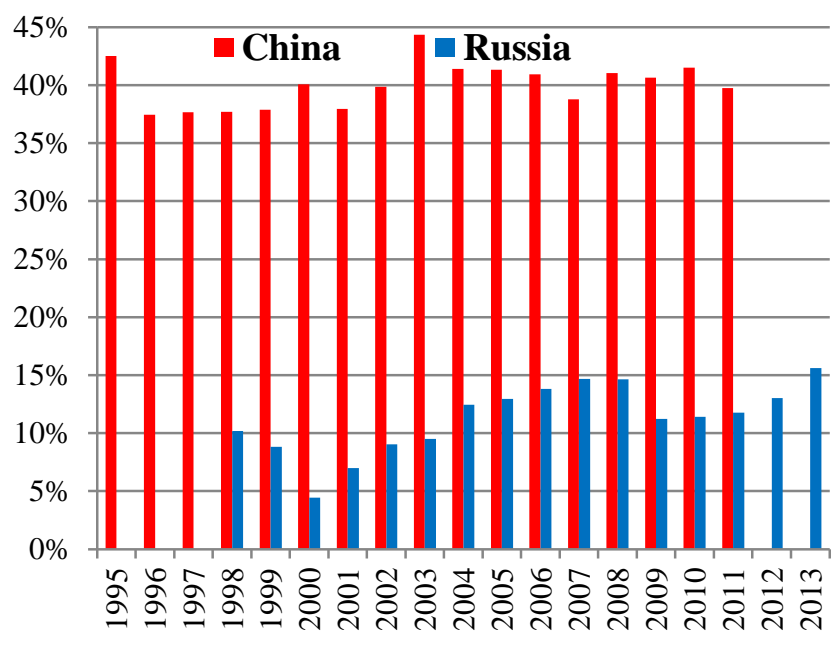

(b) The share of domestic bank loans in external sources of investment into fixed assets

Source: author's calculation based on data from [Росстат, 2014; CBRC, 2013; National Bureau of Statistics China]

Fig. 7. Domestic bank loans as a source of non-financial company investment into fixed assets

\footnotetext{
${ }^{4}$ Under external resources we mean the difference between the total amount of investment into fixed assets from all sources and the amount of self-financing of that investment by the enterprises themselves.
} 
The share of the state budget as a source of funds for fixed assets investment is higher in lower in China (4\%-5\%) than in Russia (20\%). The total budgetary expenditure in China also looks more modest than in Russia, at $24.8 \%$ of GDP vs. 37.1\% of GDP [IMF, 2014, p.74]. Out of the context, these facts could be interpreted as China's departure from centralization and re-distribution of financial resources. Our hypothesis instead suggests that state budget financing is replaced by lending from state-controlled banks. The government of China holds the leading financial institutions so closely that they are, in effect, arms of the treasury [The Economist, 31.08.2013]. In order to test this statement, we aggregate the flow of budget funds into fixed assets of non-financial companies with the flow of loans disbursed by the core state-controlled banks (expressed through a change in the loan portfolio year-on-year) ${ }^{5}$. From 2000 through 2013 , the combined flow of funds from both sources averaged 9.4\% percent of annual GDP in China and just $4.8 \%$ in Russia. Budget funds and loans from state-controlled banks complement each other (Fig.8 and Annex 8).

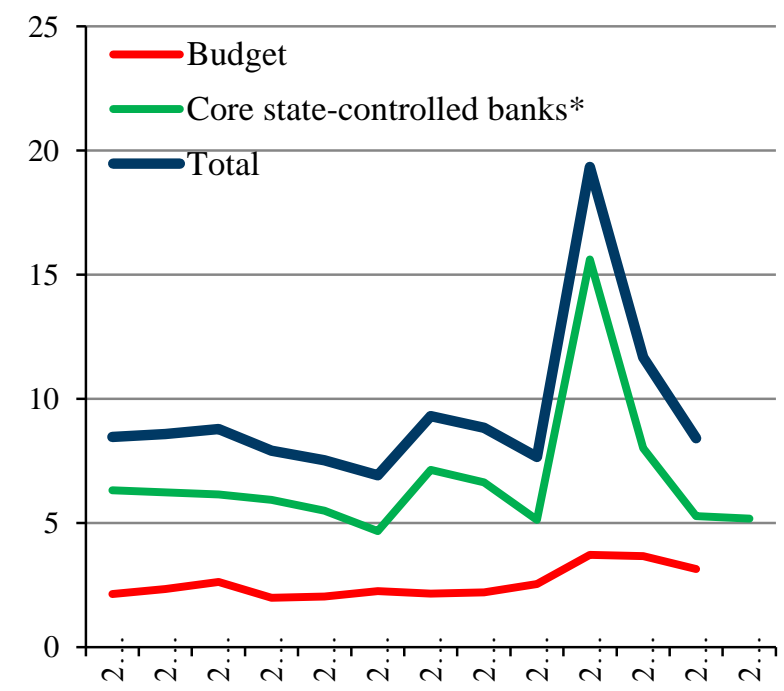

(a) China

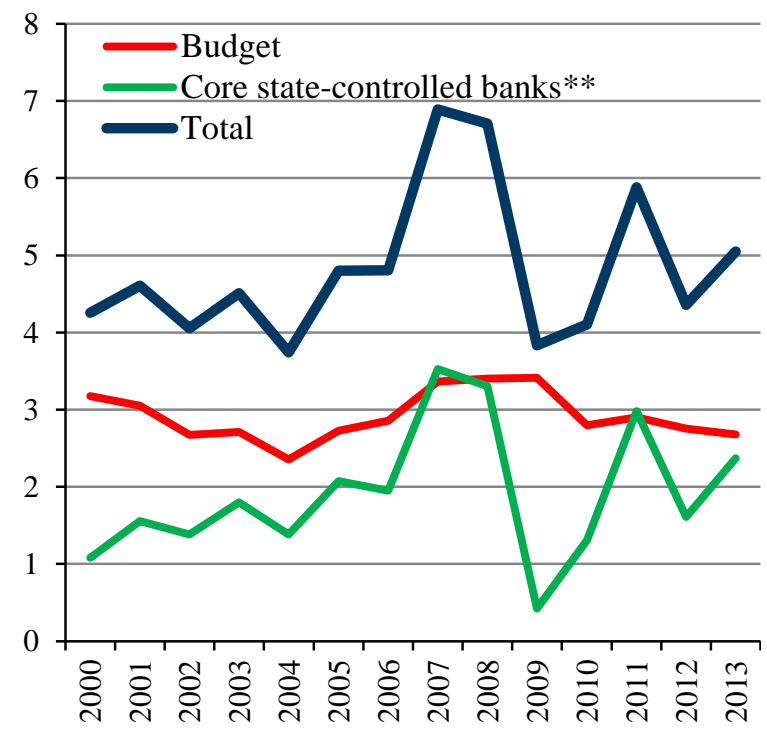

(b) Russia

Source: author's calculation based on data from CBR; Rosstat, 2014; CBRC, 2013; National Bureau of Statistics China

Fig. 8. The sources of investment for non-financial companies ( $\%$ of respective country annual GDP)

\footnotetext{
${ }^{5}$ In the absence of more reliable proxies, we assume that a change in the size of the loan portfolio features the investment activity of the core state-controlled banks. For the sake of compatibility with yearly volume of budgetary expenditure, we transform stock indicators (assets or loans outstanding for a given date) into a flow indicator (growth or contraction of the loan portfolio that occurred within one period of observation. For Russia it was feasible to compute the share of loans that goes to the non-financial enterprises; for China it was not. Data for China therefore include all bank loans, including consumer loans.
} 
In Russia the flow of budget funds are slightly more sizeable or equal to the flow of loans, except for the period of financial crisis of 2008-2009 when lending collapsed. In China, we see the opposite: lending by the «large commercial banks» by far exceeds budgetary investment. During the financial crisis of 2008-2009, the Chinese banks swiftly expanded their lending instead of cutting it. Unlike many other countries, the Chinese economy did not contract during that period.

\subsection{Government interference into bank lending decisions}

According to Speranskaya, the real sector lending plays different roles in China and Russia. China's speciaized state-controlled banks issue directed loans provided for in the national budget and the strategic economic programs. By contrast, in Russia the government that controls a growing amount of bank assets, presumably does not interfere in the banks' lending decisions. Banks reportedly pursue profitability and efficiency in their lending [Speranskaya, 2009].

The lending policy of state-controlled banks and their risk-taking behavior should help identifying exogenous interference in lending decisions, if any. Empirical studies on Chinese and Russian banks provide sufficient proof to this hypothesis. Large state-owned commercial banks do not differentiate the pricing of the credit risk nor take into account the borrower's profitability when making lending decisions [Podpiera, 2006; Fungáčová, Poghosyan, 2011, p.22]. Interest rates that banks quote for credit products of strategic importance or social sensitivity (e.g., mortgage loans) may occasionally feel the influence of the government. During financial turmoil they reduce lending to the national economy to a lesser degree than banks representing other forms of ownership [Fungáčová, Herrala, Weill, 2013]. These findings can be interpreted as effects of directed lending by state-controlled banks whose lending decisions take into account a broader set of data than merely financial efficiency and creditworthiness of the borrower.

Unlike their US or European counterparts, China's banks make part of a closed system as levers by which the government can control the economy [Cooper, 2012]. The banks serve as transmission mechanism for monetary policy. In 2009-2010 the authorities considered that the economy needs an injection of liquidity to prevent depression that had struck other countries, and banks responded by increased lending. That refers to banks controlled by the government directly as well as to nominally private or publicly floating banks [Fungáčová, Korhonen, 2011]. CBRC and PBC disclose in their reports that banks receive guidance regarding the desirable amount of credit creation and credit allocation among sectors and regions. That guidance stems from the targets of 
the 5-year development plan (the 12 $2^{\text {th }}$ 5-year plan is under implementation from 2011 through 2015). Each of China's provinces also has its priority sectors and areas. Every lending institution of relevance is expected to contribute to national targets by allocating credit accordingly. The authorities influence loan interest rates.

As for Russia, some 10 or 15 years ago the banks with government participation in the equity appeared as pursuing their own criteria of profitability and efficiency without government intervention into their lending decisions [Speranskaya, 2009]. Top managers of Russia's largest banks have declared that financial performance and market capitalization are their main objectives. That is changing now. The official Strategy for the banking sector development until 2015 indicates that Russian banks are expected to play a greater role in financing innovations in the real sector of the economy [Strategy, 2011, p.8]. The core state-controlled banks need to combine commercial banking with the implementation of the investment and structural policies [Vernikov, 2014]. The government gradually builds up its influence on the resource allocation by the core banks such as Sberbank, VTB, Rosselkhozbank or Gazprombank. Government bodies now regulate the involvement of the core banks in investment projects, including those with foreign policy implications ${ }^{6}$. Many of those projects happen to be too costly or unnecessary. In the period preceding the 2014 Winter Olympic Games in Sochi, the state-controlled banks lent to construction projects related to the games. In view of weak commercial viability of those projects the banks have to demand government assistance to cover the potential loan losses.

Apart from lending state-owned enterprises and state-sponsored projects, there are also quasi-fiscal operations aimed at discreet financing of the government. The Chinese banks were forced to lend large amounts to so-called Local Governments Financing Platforms, or LGFP, that used most of the funds to finance real estate and development. The indebtedness of regional, provincial and local governments on LGFP financing has become a threat nation-wide and no solution is in sight. Russia has also announced plans to engage state-controlled banks in the

\footnotetext{
${ }^{6}$ The Government of Russia issued on July 30, 2013 Resolution No 1343-p containing a list of investment projects whose servicing and financing is to be carried out solely by Sberbank, Gazprombank and VTB.

In October 2013 Russian issued to Ukraine a loan of RUB 750 million, with the President of Russia being aware, according to his statementr (http://top.rbc.ru/economics/08/10/2013/881078.shtml). Shortly before, Moody's downgraded Ukraine's sovereign rating to a B3 level that is close to a default level. It probably was a case of lending under the government guidance, although nominally it was a «normal» loan subscribed by state-influenced commercial banks.
} 
financing of regional budget deficits ${ }^{7}$. This financial innovation is similar with China's bank loans to LGFP. Despite the negative experience in China, Russia is set to try it.

To sum up, some 10 or 15 years ago China did differ a lot from Russia in government influence on banks' lending decisions. These days there is less of a difference. Russia apparently goes the Chinese way.

\section{Government policy towards banks}

\subsection{Industrial policy}

China started in 1978-1984 the departure from a mono-banking system and its conversion into a plural-banking system consisting of a central bank and various kinds of financial institutions [Okazaki, 2007, p.7-8]. The Soviet Union launched a similar reform a few years later, in 1987, by establishing the specialized state-owned banks (spetsbanki) [Zakharov, 2005; Krotov, 2010]. The essence of both reforms was much the same, and the names of Russia's spetsbanki were identical to the Big Four banks in China. ${ }^{8}$

The early 1990s became a bifurcation point. In 1984 China fostered its efforts to improve the efficiency of its largest banks by converting them into state-owned commercial entities. Russia acted otherwise. Instead of corporatizing and commercializing the spetsbanki it abandoned them to breakup, looting and destruction. The spetsbanki except Sberbank underwent what Schoors calls «spontaneous privatization» [Schoors, 2003]. Sberbank survived accidentally; influential lobbyists demanded Sberbank dismemberment and privatization, presumably for the sake of demonopolization. The crisis of 1998 completed the demolition of the spetsbanki system. At the turn of the century Russia started recovering its public sector of the banking industry through organic growth of Sberbank and the new generation of state-influenced banks and via gradual acquisition of domestic private banks.

\footnotetext{
${ }^{7}$ In May of 2014 the government ordered the largest banks (VTB, Sberbank and Rosselkhozbank) to engage in lending to regional budgets to cover their deficits. The cost of funding should not exceed the CBR key rate plus $1.25 \%$, and the proceeds would go to refinance earlier loans [Gazeta.RU 22.05.2014].

${ }^{8}$ Specialized state-owned banks in China were the Big Four, namely Industrial and Commercial Bank of China (ICBC), Agricultural Bank of China (ABC), Bank of China (BoC) and China Construction Bank (CCB). The USSR set up Sberbank [Savings Bank of the USSR], Promstroybank [Industrial and Construction Bank of the USSR], Agroprombank [Agroindustrial Bank of the USSR], Zhilsotsbank [Housing and Community Bank of the USSR] and Vneshekonombank [Bank of the USSR for Foreign Economic Affairs].
} 
Like 25 years ago, several largest state-controlled banks are nowadays at the core of the banking system in China and Russia. These banks lead in terms of balance sheet size, market share, number of employees, branch network and other parameters. China keeps the Big Four plus the Bank of Communications (BOCOM) in its leading group of «large commercial banks», as they are referred to in CBRC Annual Reports. Russia now has Sberbank, VTB (jointly with its subsidiaries), Rosselkhozbank and (with some reservations) Gazprombank. The upgrading and support of the national champions is at the center of the government's industrial policy with regard to banks in China and Russia. The top state-controlled banks enjoy large-scale financial support by regular replenishments of capital and placements of liquidity for long tenors and at sub-market rates, in particular for the purpose of takeovers domestically and internationally. Banks that benefit from the public support return the favor by lending to strategic industrial companies and by investing into high-profile project in infrastructure, industry and defense. State-owned enterprises may be receiving about a half of all loans issued by the largest state-controlled banks [Fungáčová, Korhonen, 2011, p.25].

Both countries achieved progress in corporatizing and commercializing their top public sector banks. It enables improving these banks' efficiency, management and governance practices. ${ }^{9}$ Raising foreign investment into the equity of these banks via public offerings and private placements to foreign investors is another means of solving the same objectives: an injection of foreign equity, albeit a minority one, increases a bank's efficiency [Berger, Hasan, Zhou, 2009].

China's authorities have pursued their industrial policy towards banks explicitly. The authorities have contributed to the emergence, development or disappearance of entire classes of financial institutions. The government presumes to have a clear idea what kinds of banks, and how many of them, it takes to attain each socio-economic objective. «Large commercial banks» appear as a separate category in the statistical materials, and policies towards these particular banks are spelled out separately. One may guess that the market share of these banks is to drop to around onehalf of commercial banks total assets.

Russia has been implementing an implicit industrial policy towards banks. It is unclear whether the authorities want to see the market share of their core banks grow or fall. Official

\footnotetext{
${ }^{9}$ When these banks' financial performance (market capitalization, return on equity, etc.) is over-emphasized, it distracts them from the implementation of their essential mission and important macroeconomic goals.
} 
blueprints and strategies speak about all banks in general terms of «primarily intensive development model», enhancement of competition, transparency and market discipline, «equal playing field for all lending institutions regardless of their size and ownership form» [Strategy, 2011]. These vague concepts are irrelevant to the reality of the Russian banking market.

There is no clear watershed between the leading commercial banks under government control and the development banks. In theory, the development banks were supposed to take over the official financing of state-sponsored projects and structural policies. In practice, however, both types of lenders engage in project finance, corporate finance and trade finance and take part in the national investment programs. The lending by the development banks in both countries and China's «policy banks» has an impact on the market environment for ordinary banks. The leading statecontrolled banks in China and Russia are nominally joint-stock companies and commercial entities. Nevertheless, their activity is a mixture of commercial banking and development lending. We interpret this as a reflection of the similarity in their nature and mission. An entity can migrate from one category to another. In Russia there were proposals that Rosselkhozbank (the bank for agriculture) give up commercial lending and turn into a «state corporation» [RBK, 21.02.2014]. In such a case the bank would become similar to China's «policy bank», the Agricultural Development Bank of China $(A D B C)$, that finances structural change in the agro-industrial sector and rural areas.

\subsection{Ownership transformation}

Speranskaya sets Russia's state-influenced banks in opposition to China's state-owned banks [Speranskaya, 2009]. These two distinct terms make one presume that bank ownership structure in China and Russia differs in essence. If such differences indeed existed some time ago, they have diminished, in our view. The largest banks controlled by the authorities in China and Russia have been transformed into public joint-stock companies. Most of them floated their shares through an IPO. Except for the Russian Rosselkhozbank, they all now have a sizeable minority participation in their equity, including foreign portfolio investors. This process started in China earlier than in Russia. The official rhetoric in both countries uses the term «privatization» widely and liberally to describe the bank ownership transformation. A genuine privatization, however, implies transfer of control from the government to non-affiliated private capital, which hardly ever happens to one of the leading state banks. In many cases the new external shareholders, both domestic and foreign 
ones, are affiliated with the host country authorities. They accept passive shareholding in exchange for a steady growth of market value and dividend flow.

We see in China a restructuring of the public sector of banking. The market share of secondand third-tier banks is growing at the expense of the «Big Five» banks (Annex 5-a and 5-b). In Russia the market share of the top state-controlled banks is still rising, but so is, and at a faster pace, the share of indirectly state-controlled institutions (Annex 5-c) ${ }^{10}$. This phenomenon can reflect a greater diversification and sophistication in the modalities of the state equity participation. Central executive bodies transfer ownership rights downstream to the other state entities, holdings, funds, corporations, banks, regional authorities, etc. The Russian federal authorities keep the controlling stakes of the three top banks. In China, by contrast, the national-level authorities may keep in their hands a minority stake, e.g., 39\% of equity at $\mathrm{ABC}, 35 \%$ at $\mathrm{ICBC}$, and $32.4 \%$ at BOCOM; and delegate the rest of the government stake to state-influenced holdings and investment funds. One of China's special features is the significant role of the regional and even lower-level authorities in the ownership and governance of banks, as compared to Russia. One should of course bear in mind the scale of the country where one province can have the size of an average European economy.

The rationale for the delegation of ownership rights downstream is debatable. Additional management levels and the complexity of governance structures broaden the opportunities for opportunistic behavior of managers of all the entities involved and intensify the agency problem. It results in increased governance and management costs, funds diversion, and corruption. The replacement of direct government ownership by indirect ownership might signal different phenomena: either an on-going commercialization of public entities and improvement of their efficiency, or asset stripping in the public sector in favor of influential insiders and primarily the top managers of the state banks and corporations.

Central authorities usually transfer and delegate ownership rights to other entities while maintaining ultimate control over the disposal of the property. The subjects receiving the property run it with due regard to the priorities and preferences of the superior authorities. State-controlled or, for that purpose, nominally private banks receive financial funds from the government and spend a

\footnotetext{
${ }^{10}$ Indirectly state-owned banks are sometimes featured in the literature as quasi-state-banks. We find this term imprecise and prefer to feature such banks as quasi-private. They possess formal and legal features of a private entity but they are capitalized mainly by funds of public origin or they have access to public money for funding.
} 
part of these funds to finance projects or borrowers at the government's choice. We regard this system as a manifestation of the institution of superior conditional ownership that historically has prevailed in Russia with regard to the core means of production [Kirdina, 2003; 2014, p.107]. Superior conditional ownership is neither public nor private; its «privatization» is always provisional and can be reversed legally or otherwise.

The government and Central Bank of Russia in their strategic blueprint for the banking sector envisage a reduction of government participation in bank equity down to the level of simple control in the medium run and below the control level thereafter [Strategy, 2011, p.9]. We expect this plan to materialize only partly if at all. New circumstances are slowing down the withdrawal of the government from the equity of the core banks.

\subsection{The treatment of foreign investment into bank equity}

Foreign-funded banks in Russia enjoy national treatment with few exceptions. Russia from the outset permitted the establishment of 100\%-owned foreign bank subsidiaries. Some of them now appear in the Top-20 ranking of Russian commercial banks. China, by contrast, has been ruling out direct foreign control over domestic banks for a long time. At the same time, China did allow foreign bank branches, which Russia did not. Since 2007 approximately the thrust of the regulation shifted towards encouragement of locally incorporated banking entities funded by foreign capital. By the beginning of 2013 there were 95 foreign bank branches and 42 banks locally incorporated in China that, in turn, had 275 branches and sub-branches nation-wide [CBRC, 2013]. Foreigncontrolled banks do not enjoy national treatment in China and face a variety of restrictions. For instance, each subsequent branch requires a new permission; operations in the national currency, RMB, become possible only 3 years after establishment. In Russia all new banks immediately get the right to transact in Rubles. At the same time, China's experience suggests that under due regulation the foreign bank branches represent no threat whatsoever for the host economy and monetary system. The branches that were set up over the previous years are not harassed. Rather their owners find it more beneficial to launch a locally incorporated entity in China. The experience of China in this filled is disregarded and silenced out in Russia because it mismatches Russia's political environment, namely the strong negative attitude towards foreign bank branches. 


\subsection{Deposit insurance}

Russia has an explicit deposit insurance system since 2004. China has not (yet) introduced a staterun explicit deposit system. Nevertheless China keeps its 13 percentage points lead over Russia in terms of the proportion between bank deposits and GDP, as was the case in 1994 (Fig.1-b). Statecontrolled banks dominate the market for household bank savings in both countries, these banks' market share in Russia being around 60\%. The government as the key shareholder bears in any case subsidiary liability for all debt of its financial institutions, regardless of the presence or absence of an explicit system of deposit insurance in the country.

China has been reported to prepare the introduction of an official system of deposit insurance within the current $12^{\text {th }}$ five-year planning period [Bloomberg, 20.04.2014]. The expectation is that the liberalization of interest rates on private deposits will increase the cost of funding for small nonstate-owned financial intermediaries or even trigger their insolvency. Deposit insurance system should extend in time the outflow of deposits from small savings institutions (not only banks) to large market operators all of which are state-controlled.

Like all deposit insurance schemes worldwide, the Russian one aimed to improve confidence, facilitate the inflow of household savings into banks and prevent depositor runs on their banks. Its true purpose, however, was to enhance the competitiveness of private domestic banks whose absolute majority did not enjoy depositors' trust. In the absence of a deposit insurance scheme, those banks would fail to raise sufficient resources, lose out in the competition and soon quit the market. Neither state-owned banks nor large foreign players felt the need for a deposit insurance scheme or supported its introduction. In essence, the government employed the institution of deposit insurance as a mechanism slowing down structural change in the banking industry. In its absence, the state-controlled banks would have restored their market dominance faster and, jointly with foreign-owned banks, phase out domestic private banks. This institution artificially kept afloat domestic private banks. For this reason, we regard the institution of deposit insurance in the context of the government's industrial policy towards banking. The deposit insurance scheme achieved its goal in the sense that several hundreds of small banks got a second chance, extended their existence and remained in the market place. The Russian experience with deposit insurance illustrates numerous defects of such a scheme. The main one relates to moral hazard, or the erosion of moral and ethical principles and the promotion of destructive behavior, irresponsibility, opportunism, etc. 
by both the depositors and their banks [Karas, Pyle, Schoors, 2013]. Deposit insurance intensifies price competition and undermines the financial sustainability of smaller banks instead of producing the opposite effect. The presence of deposit insurance gave birth to a huge criminal business with asset stripping, illegal funds withdrawal from the banks and illegitimate compensations after a bank failure.

\section{Synthesis and results interpretation}

We now draw on the material in the preceding sections to attribute signs reflecting our subjective judgment regarding two questions: (a) does essential similarity or difference prevail at the current stage; and (b) does the evolution go in the direction of convergence or divergence. The following Table summarizes the main results of the comparison of the institutional structure between the two banking systems.

Table. Comparison of the banking systems of China and Russia

\begin{tabular}{l|l|l|c|c}
\hline & Static: & $\begin{array}{c}\text { Dynamic: } \\
\text { similarity (+) } \\
\text { convergence } \\
\text { or } \\
(+), \quad \\
\text { China } \\
\text { divergence (-), } \\
\text { no change (=) }\end{array}$ \\
\hline
\end{tabular}

\section{Institutional structure}

The number of commercial banks, and

- the direction of its change

Geographical outreach: bank entities per:
- 100,000 adults
- 1,000 km2;

54

$\uparrow \quad \downarrow$

$9.16 \quad 2.83$

$7.7 \quad 38.2$

Multi-tier and hierarchically organized system of commercial banks led by the core state-controlled banks

A bank-based model of financial intermediation

Financial depth (bank assets to GDP), \%

\section{Market structure and concentration}

Supremacy of large state-controlled banks

Yes Yes

$+$ $=$

The market share of the:

- core state-controlled banks, $\%$

44.9

42.4 
- other state-controlled banks, $\%$

- domestic private banks, $\%$

- foreign-controlled banks, $\%$

$\begin{array}{cccc}\approx 50 & 17.3 & - & + \\ 3 & 25 & - & = \\ 2 & 15.3 & - & = \\ 78 & 63 & + & =\end{array}$

The industrial policy of the government

Nurturing «national champions» within the public sector:

- official industrial policy

- the actual policy of the government

The core state-controlled banks are at least as efficient as other market participants

A genuine privatization of the core state-controlled banks

Yes No

Yes

Yes Yes

Yes

Yes Yes

A more diversified equity structure of the core state-controlled banks (corporatization, external shareholders)

$+\quad+$

Favorable treatment of foreign subsidiary banks

Favorable treatment of foreign bank branches

An explicit scheme of deposit insurance

Yes Yes $+\quad=$

Yes No - =

No* Yes $\quad-\quad+$

Bank involvement in the lending to the non-financial sector

Domestic bank lending is an important source of investment into fixed assets of non-financial companies

Yes No

No

Lending by the core state-controlled banks complement budgetary funds invested into fixed assets of non-financial companies

Government bodies interfere into the lending decisions of the core state-controlled banks

Yes Yes

$+\quad=$

The core state-controlled banks combine commercial banking with development banking

Yes Yes $+=$

Government bodies exert influence on the lending decisions of nominally independent banks

Yes Yes + =

Bank lending covers the budget deficit of the regional and local authorities

\section{Total}

Yes No - =

Yes $\mathrm{No}^{*} \quad-\quad+$

\begin{tabular}{cc}
+12 & +8 \\
-14 & $=18$ \\
& -1 \\
\hline
\end{tabular}

\footnotetext{
* Envisaged.
} 
The Table above suggests that statically there are quite a few differences and incoherencies. However, in dynamics the trend goes in the direction of greater coherence between the institutional structure of the banking system in China and in Russia. Only one parameter displays a reverse dynamics, namely the market share of the core state-controlled banks.

Russia went further than China in liberalizing its banking industry in the early 1990s. The subsequent development was non-linear. China combined a transformation of the state-controlled banks and a reduction of their market share with the employment of more sophisticated tools of monetary policy. One could interpret that as a departure from a «socialist» model of a credit system in the direction of a market-like commercially oriented system governed by competition [Okazaki, 2007, p.25; Xu, van Rixtel, van Leuvensteijn, 2013]. In Russia the past 10 or 15 years gave what looks like evidence of a stronger public sector and an ever narrowing field for competition in banking. Taken out of the context, statistical data might suggest that development paths diverge. Would such an interpretation be accurate, and is it true that China's model of banking aims at an «authentic market», whereas Russia's is pointed in the opposite direction? We do not think so, in view of the large (and ever growing) number of similar institutional forms and structural features in the two banking systems (see previous sections).

Western scholars recognized a decisive role of the state in both countries' economies. They still choose to believe that the evolution goes in the direction of capitalism and market [Puffer, McCarthy, Wilson, 2007]. Some would say in the early 1990s that the completion of China's transition to a market system was within sight [Perkins, 1994]. We argue that the mainstream paradigm that sets «socialism»against «capitalism» or «market» fails to describe the social dynamics in China. The Chinese themselves have merged these two seeming extremes into one term, «socialist market economy» (see Wikipedia).

The theory of institutional matrices or TIM [Kirdina, 2001; 2014] allows inserting the developments in a particular sector (e.g., commercial banking) into the socio-economic context of Russia and China. According to the TIM, both national economies feature a dominance of the institutional X-matrix that implies centralized non-market re-distribution as well as superior conditional ownership. The prevalence of the X-matrix or the Y-matrix is invariable («path dependence»), therefore the lead of the given type of institutions persists. Attempts of doublecrossing by replacing cardinal institutions with those from an alternative matrix are doomed. 
The survival of the system and its efficient functioning depends on the balance between dominant institutions and complementary ones. A forward-looking trajectory must comply with several criteria including a static and a dynamic complementarity of institutions and a rational sequencing of the institutional change [Polterovich, 2006]. Sustainable development requires the proportion of 65:35 or 70:30 (close to the « golden ratio») between dominant and complementary institutions [Davydov, 1988; Kirdina, 2001].

Banks' main function in X-type and Y-type economic system alike is transforming savings into investments and allocating/reallocating monetary resources between subjects. The TIM predetermines the specific form of resource allocation for the given type of society. Kirdina develops a theory about two basic institutional models of real sector financing, namely «state as investor» and «state as regulator». China and Russia both represent the X-type of economy, so they adhere to the former model; the US economy belongs to the Y-type, so they adhere to the latter model [Kirdina, 2013]. The dominant form of resource allocation in an X-economy is centralization and subsequent redistribution under the guidance of the government. The complementary institution in this case rests in the decentralized raising of resources from the financial market and their allocation according to financial efficiency. Correspondingly, the state-controlled banks and their financing for government programs and projects appear as serving the dominant institution of resource allocation for the X-economy. Then privately owned banks' activity in the accumulation of savings and their investment into financial market assets relates to the functioning of the Y-type institution. Together they ensure a needed proportion and balance in the financial system.

The above paradigm enables interpreting various phenomena. China is moving gradually but consistently from a total dominance of one type of institutions, those of centralized redistribution of financial resources, to a more balanced mix of those plus the resource allocation via market. Private capital remains underrepresented in the banking system, so its share is set to grow. Maintaining a proportion between different types of institutions preserves the stability of the financial system and the trust of the population and sustains economic growth.

Russia attempted in the 1990s to reverse at a single throw the operating mode of the credit system by crushing the embedded institutions. The government withdrew itself from the reallocation of credit resources and encouraged the breakup of the spetsbanki system. In parallel to that, domestic private capital was burgeoning quickly and unrestrained until it came to control around two-thirds of 
the banking industry by the end of the same decade. Hundreds of privately owned banks emerged practically from scratch, out of nowhere. At its peak, the number of commercial banks in Russia exceeded 2,400. That crowd failed to deliver. Banks were extending little financing to the rest of the economy but instead were preying on Russia's fiscal weaknesses. By mid-1998, the share of government securities reached $32.1 \%$ of the banks' total assets, which exceeded the share of loans to non-financial enterprises (28.5\%) [CBR, 2002, p.10, Table 9]. The banking system melted down and the largest banks went bust during the crisis of 1998. The posterior developments can be featured as institutional self-adjustment, within the TIM paradigm. The pre-crisis proportions between public and private capital in banking and between centralized redistribution and market had shifted far away from the historical equilibrium. That was an overshooting. Since 1998 the proportion started recovering. The state build up its relevance as a regulator, a systemic programmer and a producer of banking services in its capacity of controlling shareholder at the largest commercial banks and development lenders. A growing share of resources now flows via these channels. The government learns how to influence the level of bank loan interest rates of all participants. As a result, there is less room for private initiative and market exchange.

To sum up, each of the two banking systems migrates to a specific proportion between the dominant X-type institutions that centralize and redistribute financial resources and the complementary Y-type institutions that ensure the workings of the market demand/supply and competition. We assume that the number of active commercial banks, the majority of which are privately-owned, denotes a liberalization of the banking sector and the strength of the private initiative. On an inverted scale the trend line for Russia goes deeply down and then reverses the direction, while the trend line for China goes down slowly (Fig. 9-a). In a similar fashion, we view the market share of state-controlled banks as a proxy for the strength of $\mathrm{X}$-institutions of centralization and redistribution (Fig.9-b). The trend line for China displays a similar shape as in the previous case ${ }^{11}$. The trend line for Russia apparently does not, only due to the absence of precise data on the market share of state-controlled banks in the 1990s. If we could insert those data in the

\footnotetext{
11 The trend line for China on the Fig. 9-b goes downward rather steeply. The 5 "large commercial banks" represent a significant part of the public sector of the Chinese banking industry but not its entirety. As we argued in the section 3.3, the majority of joint stock, city and rural commercial banks received their initial funding from the government and remain closely related with the authorities. The market share of the entire public sector would therefore appear on the chart as a line almost parallel to the time axis and only lightly declined downwards. Absence of precise data impedes drawing it.
} 
chart 9-b, it would assume a V-shape. Fig.9-c reflects our graphical vision of the shifting proportion between X- and Y-institutions in China and Russia. Diverging paths are therefore an illusion. These paths are actually converging from different starting points 15 or so years ago.

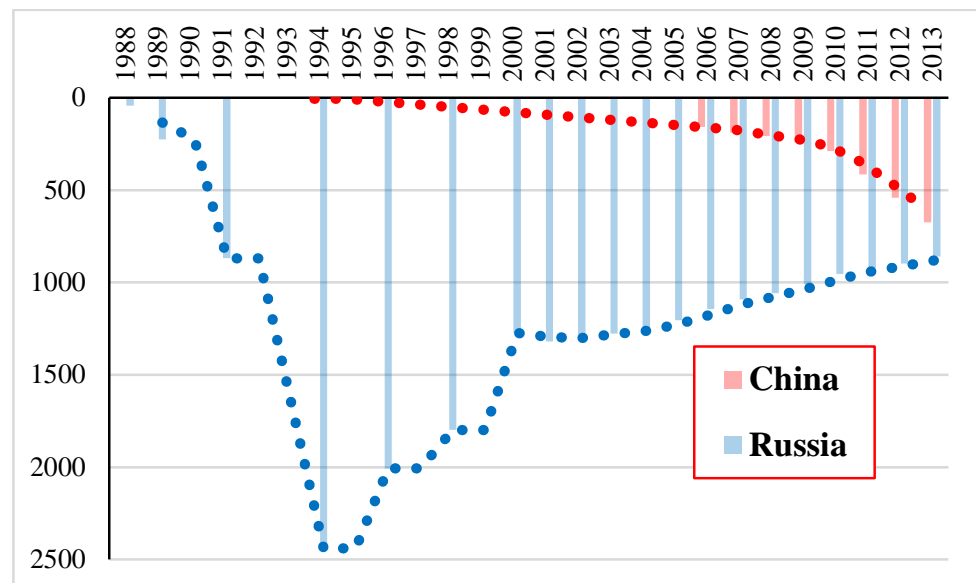

(a) The number of commercial banks (inverted scale)

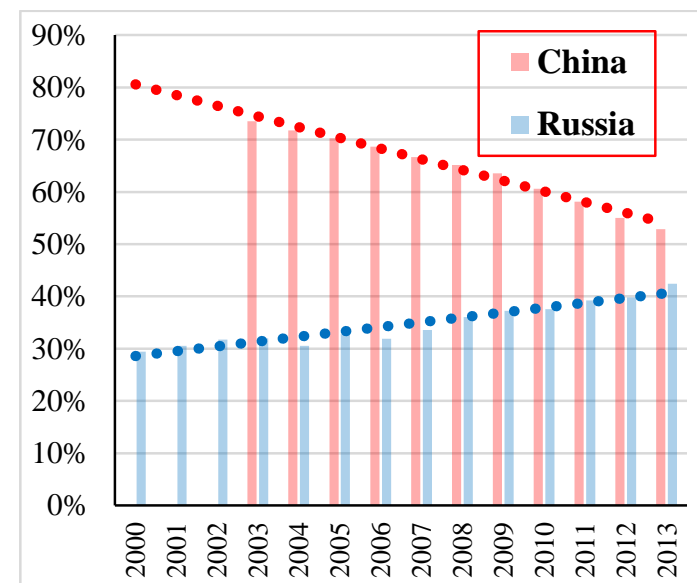

(b) The market share of the core state-controlled banks

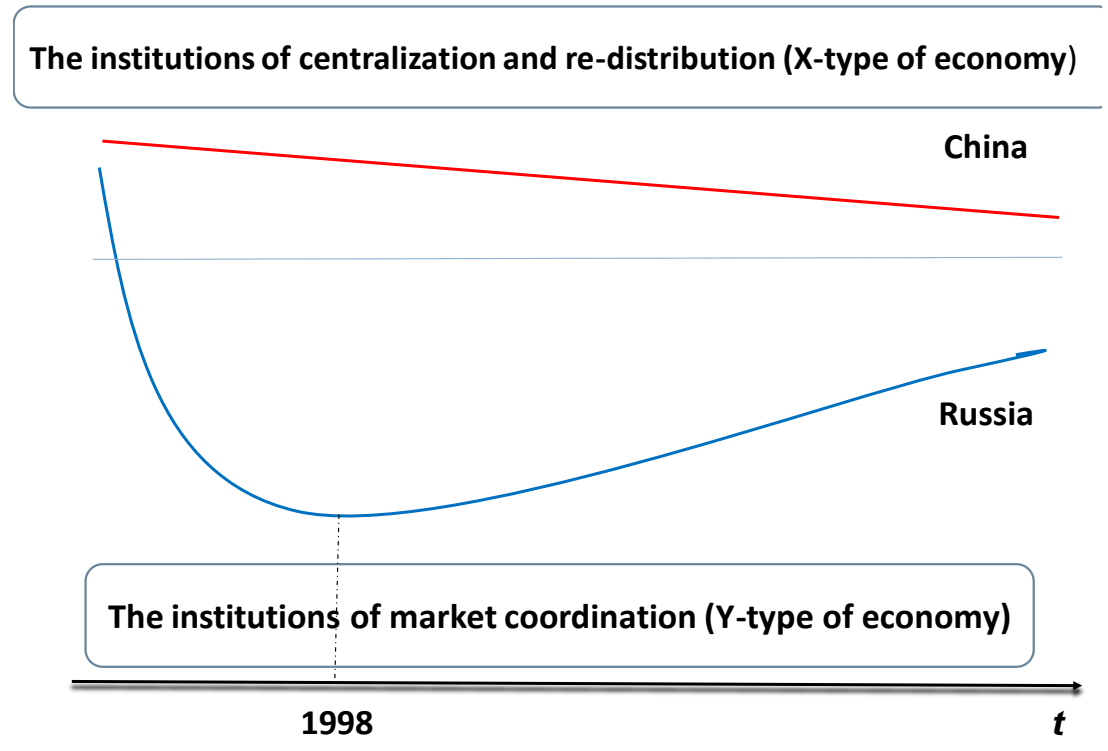

(c) a changing proportion between two types of institutions

Fig. 9. The direction of the institutional change in the Chinese and Russian banking

The typological coherence between the banking systems of China and Russia touches upon the interesting topic of the direction of institutional transfer. In the second half of the $20^{\text {th }}$ century China relied to a certain degree on the experience of the Soviet Union, learning from the practice of centralized planning, structural policy, enterprise cost-accounting, etc. The direction of institutional 
imports changed in the early $21^{\text {st }}$ century as China became the donor of institutions and institutional forms for Russia. We refer to the large state-controlled banks, their corporatization and commercialization and the combination between commercial banking with development lending; the delegation of ownership rights from the central government to other entities within the public sector; «dirigisme» over bank lending decisions; bank financing of regional budget deficits; the development of a national system of payment cards à la China UnionPay; regulation of interest rates

for bank deposits and loans; and the network of development institutions. Examples of institutional transfer in the opposite direction, from Russia to China, are much harder to identify. Probably China took into account the Russian experience with foreign-controlled banks when it started encouraging locally incorporated foreign-owned institutions rather than foreign bank branches.

There is a special case of institutional engineering, namely the introduction of state guarantee / insurance of household bank deposits. Such a system already is in existence Russia and may soon emerge in China. However, in both countries there have been large state-backed players in the household deposits market. It means that the government is already bearing ultimate liability for a large share of private savings. Instead of balancing the traditional paternalism of the state and the people's infantilism with some new mechanism of market discipline, the government introduces deposit insurance that adds one more circuit of paternalism. It further erodes market discipline and aggravates moral hazard, thus adding fragility to the banking system. We view deposit insurance as an alien institution for China and Russia that serves some tactical political goals but goes against the general logic of the system. Russia has already discovered the fallout from deposit insurance; China has yet to discover it.

\section{Conclusion}

We pull through the size mismatch and the social and cultural difference between China and Russia in search of evidence that would address the following questions: Is the Russian banking system coherent with the Chinese one in its essential features? Do their evolution paths converge or diverge? We compare the institutional setup, market structure and concentration, the industrial policy of the government in banking, and the relevance of banks for non-financial sector financing. The general finding is that statically there are common points and distinctions, while dynamically the elements of convergence outnumber those of divergence. Below are some of these points: 
- A multi-tier and hierarchically organized system of commercial banks headed by several institutions under direct control of the government;

- A growing number of commercial banks in China and a falling number in Russia while bank penetration improves in both countries;

- A 42\%-45\% market share of the core state-controlled banks, with a downward trend in China and an upward trend in Russia;

- Indirectly state-controlled banks outrun other types of players in terms of market share;

- A falling relevance of domestic private and foreign-controlled banks in Russia and their stagnating market share in China;

- Aggressive industrial policy of the government aimed at nurturing a few large state banks as «national champions». The policy is explicit in China and implicit in Russia;

- Sophistication of the equity structure at the core state-controlled banks as a substitute to their genuine privatization;

- China's intention to enact a household deposit insurance system that is already in place in Russia;

- High relevance of Chinese bank loans as a source of investment into fixed assets of nonfinancial enterprises;

- State-controlled bank loans complement budgetary funds as sources of investment into fixed assets of non-financial enterprises in both countries;

- The core state-controlled banks combine commercial banking with development banking;

- The government influence over the lending decisions of the largest state-controlled banks (in China, the lending decisions of practically all relevant banks);

- An increasing «dirigisme» and directed lending in Russia that removes the most essential mismatch between the Chinese and the Russian system [Speranskaya, 2009];

- Bank lending to regional and local authorities to cover budget deficit (in place in China; envisaged in Russia).

There is more typological coherence between Russia and China than between Russia and the CEE countries that started banking reforms more or less at the same time. In the area of banking, China has actually become an institutional donor for Russia, although it is not acknowledged politically. 
The Russian banking system is gradually converging with China's.

We believe that our research offers empirical proof to some of the elements of the macrosociological theory of institutional matrices (TIM). For instance, the survival of the system demands the maintenance of a certain proportion between the dominant and the complementary institutions. China and Russia have historically developed the dominance of the redistributive Xeconomy along with the complementary institutions of the market Y-economy. China has been searching for an optimal proportion between them since the 1980s by combining different types of ownership and different mechanisms of financial resources allocation. In Russia, the proportion between economic institutions was violated in the early 1990s by the overshooting of liberalization. Unrestrained freedom for private capital produced a dysfunctional banking industry that only served itself and eventually collapsed in 1998. The state reverted to the banking system after that, if one considers the growing share of state-controlled banks, the birth of development institutions and the rise of «dirigisme» in the bank lending. We interpret this development as an institutional selfadjustment that prevents a meltdown of the system.

The Chinese and the Russian banking systems are currently drifting towards a sustainable proportion between the institutions of the redistributive $\mathrm{X}$-economy and those of the market $\mathrm{Y}$ economy. Different starting points make the trends look like diverging but they are actually converging.

This paper adds three new elements to the description of the institutional model of « state as investor» that relates to the financing of the real economy in China and Russia [Kirdina, 2013]: (a) the limited importance of bank loans as a source of investment into fixed assets of non-financial companies; (b) mutual complementarity between core state bank loans and budget /quasi-budget financing; (c) falling relevance of the nominal form of ownership. The government employs alternative instruments to ensure control over the leading banks. What matters is not the legal form of ownership but the capability to transmit to the bank the social procurement. One of the avenues is the government influence on bank lending decisions.

Lastly, we mention deposit insurance as a case of possibly counterproductive institutional engineering. In this author's opinion, deposit insurance is an alien and redundant institution for both Russia and China. The institutional dynamics that we envisage does not easily accommodate the long-term thrust of the Russian authorities to divest from the equity of the core state-controlled 
banks. Unbiased research fails to deliver exhaustive evidence of a strong positive relationship between privatization and efficiency improvement [Polterovich, 2012, p.20]. The intention of the government to get rid of its banks for the second time in a row and to withdraw from the loan market would bring similar consequences like in the 1990s. After some time, core banks will need to be restored anyway.

\section{References}

Allen F., Gale D. (2000), Comparing Financial Systems, MIT Press, Cambridge, MA and L.

Berger A., Hasan I., Zhou Mingmin (2009), Bank ownership and efficiency in China: What will happen in the world's largest nation?, Journal of Banking and Finance 33(1): 113-130.

Bonin J., Hasan I., Wachtel P. (2005), Bank performance, efficiency and ownership in transition countries, Journal of Banking and Finance 29(1): 31-53.

CBR (2002), Obzor bankovskogo sektora Rossiyskoy Federacii [Survey of the Banking Sector of the Russian Federation], No 1 (Internet version), Central Bank of Russia, Moscow, November 2002 [in Russia]

(2014), Banking Supervision Report in 2013, Central Bank of Russia, Moscow, 2014 [in Russian]

CBRC (2013), Annual Report 2012, China Banking Regulatory Commission, Beijing.

CBRC (2014), Annual Report 2013, China Banking Regulatory Commission, Beijing. [in Chinese]

Cooper J. (2012), Are China's banks heading for a crisis? The Banker, April 2012.

Davydov A. (1988), Suschestvuyet li mera socialnoy garmonii? [Is there a measure of social harmony?], SOCIS, No 5 [in Russian]

Demirgüç-Kunt A., Kane E., Laeven L. (eds.) (2008), Deposit Insurance around the World: Issues of Design and Implementation, MIT Press, Cambridge MA and L.

Fungáčová Z., Solanko L., Weill L. (2010), Market power in the Russian banking industry, International Economics 124(4): 127-145.

Poghosyan T. (2011), Determinants of bank interest margins in Russia: Does bank ownership matter?, Economic Systems 35(4): 481-495.

, Korhonen I. (2011), Like China, the Chinese banking sector is in a class of its own // BOFIT Discussion Papers DP 32/2011. Bank of Finland, Helsinki.

, Herrala R., Weill L. (2013), The influence of bank ownership on credit supply: Evidence from the recent financial crisis, Emerging Markets Review 15(2): 136-147.

Pessarossi P., Weill L. (2013), Is bank competition detrimental to efficiency? Evidence from China, China Economic Review 27 (December 2013), 121-134.

IMF (2011), Russian Federation: Financial System Stability Assessment, IMF Country Report No 11/291. International Monetary Fund, Washington DC, September 2011.

(2011), People's Republic of China: Financial System Stability Assessment, IMF Country Report No 11/321. International Monetary Fund, Washington DC, November 2011. 
(2014a), Public Expenditure Reform: Making Difficult Choices, Fiscal Monitor, April 2014, IMF (Washington DC).

(2014b), Financial Access Survey, Washington DC: International Monetary Fund. http://fas.imf.org/ (Last accessed in May 2014).

Karas A., Schoors K., Weill L. (2010), Are private banks more efficient than public banks? Evidence from Russia // Economics of Transition 18(1): 209-244.

Karas A., Pyle W., Schoors K. (2013), Deposit insurance, banking crises, and market discipline: Evidence from a natural experiment on deposit flows and rates, Journal of Money, Credit and Banking 45(1): 179-200.

Kirdina S. (2001), Institucionalniye matricy i razvitie Rossii [Institutional Matrices and the Development of Russia], Siberian Branch of the RAS, Novosibirsk [in Russian]

(2003), Institut zemelnoy sobstvennosti v Rossii [The institution of land ownership in Russia], Voprosy ekonomiki, No 10: 146-153 [in Russian]

(2012), From Marxian school of economic thought to system paradigm in economic studies: The institutional matrices theory, Montenegrin Journal of Economics 8(2): 53-71.

(2013), Institucionalniye modeli finansirovaniya realnogo sektora [Institutional models of real sector financing], Journal of the New Economic Association, No 2(18): 129-155 [in Russian]

, Vernikov A. (2013), Evolution of the banking system in the Russian context: An institutional view, Journal of Economic Issues 47(2): 475-484.

(2014), Institucionalniye matricy i razvitie Rossii: vvedenie v X-Y-teoriyu [Institutional Matrices and the Development of Russia: Introduction to the X-Y-Theory], Nestor-Istoria, St.Peterburg \& Moscow [in Russian]

KPMG (2012), Mainland China Banking Survey 2012, KPMG, Hong Kong

Krotov N. (2010), Istoriya sovetskoy bankovskoy reformy 80-kh godov XX veka. Vol.1 - Spetsbanki [The History of the Soviet Banking Reform in 1980s. Vol.1 - Specialized State-Owned Banks], Ekonomicheskaya letopis, Moscow [in Russian].

La Porta R., López-de-Silanes F., Shleifer A. (2002), Government ownership of banks, Journal of Finance 57(1): 265-301.

Liao Wei, Tapsoba S. (2014), China's monetary policy and interest rate liberalization: Lessons from international experiences // IMF Working Paper No. 14/75. International Monetary Fund, Washington DC.

Lin Xiaochi, Zhang Yi (2009), Bank ownership reform and bank performance in China, Journal of Banking \& Finance 33(1): 20-29.

Lu Yan, Fung Hung-Gay, Jiang Xianfeng (2007), Market structure and profitability of Chinese commercial banks, Chinese Economy 40(5): 100-113.

National Bureau of Statistics China. Sources of Funds for Investment in Fixed Assets in the Whole Country. http://www.stats.gov.cn/tjsj/ndsj/2012/html/F0505e.xls (Last accessed on 25.04.2014).

Okazaki K. (2007), Banking system reform in China: The challenges of moving toward a market-oriented economy // RAND Corporation Occasional Paper Series No RAND/OP-194-CAPP.

PBC (2014), China Monetary Policy Report. Quarter Four, 2013. People’s Bank of China, 2014. 
Perkins D. (1994), Completing China's move to the market, Journal of Economic Perspectives 8(2):23-46.

Podpiera R. (2006), Progress in China's banking sector reform: Has bank behavior changed? // IMF Working Paper No WP/06/71.

Polterovich V. (2006), Strategii institucionalnykh reform. Kitay i Rossiya [The strategy of institutional reforms. China and Russia], Ekonomika i matematicheskie metody 42(2): 3-16 [in Russian]

(2012), Privatizaciya i racionalnaya struktura sobstvennosti [Privatization and a rational ownership structure], RAS Institute of Economics, Moscow [in Russian]

Popov V. (1999), The financial system in Russia compared to other transition economies: The AngloAmerican versus the German-Japanese model, Comparative Economic Studies 41(1): 1-42.

Puffer S., McCarthy D., Wilson J. (2007), Emerging capitalism in Russia and China: Implications for Europe, European Journal of International Management 1(1-2): 146-165.

PWC (2012), Foreign banks in China 2012. PricewaterhouseCoopers Limited, July 2012. www.pwccn.com

Rosstat (2014), Struktura investiciy v osnovnoy capital po istochnikam finansirovaniya (last accessed in January 2014).

Schoors K. (2003), The fate of Russia's former state banks: Chronicle of a restructuring postponed and a crisis foretold, Europe-Asia Studies 55(1): 75-100.

Speranskaya T. (2009), An analysis of the Russian banking model versus the Chinese one // Studies on Russian Economic Development 20(2): 181-188.

Strategy (2011), Strategiya razvitiya bankovskogo sektora Rossiyskoy Federacii na period do 2015 goda [Strategy for Developing Banking Sector until 2015]. The Government of the Russian Federation No 147p-p13 and the Central bank of the Russian Federation No 01-001/1280, April 5, 2011 [in Russian]

Vernikov A. (2009), Russian banking: The state makes a comeback? // BOFIT Discussion Papers DP 24/2009, Bank of Finland, Helsinki.

(2012), The impact of state-controlled banks on the Russian banking sector, Eurasian Geography and Economics 53(2): 250-266.

(2014), State-controlled «national champions»: Implications for empirical study of Russian banks' efficiency and concentration // SSRN Accepted Paper Series No 2223565.

World Bank (2013), Financial Development and Structure Dataset (updated Nov. 2013). The World Bank, Washington DC.

Xu Bing, van Rixtel A., van Leuvensteijn M. (2013), Measuring bank competition in China: A comparison of new versus conventional approaches applied to loan markets // BIS Working Papers 422. Basel: Bank for International Settlements.

Zakharov V. (2005), Ocherky bankovskoy reformy 1988-1991godov [Essays on the Banking Reform of 19881991], Finansy i statistika, Moscow [in Russian]. 


\section{Appendix}

Annex 1.

Financial depth in China and Russia

\begin{tabular}{|c|c|c|c|c|c|c|c|c|c|c|c|c|c|c|c|c|c|c|c|c|c|c|}
\hline & & $\bar{\sigma}$ & $\widetilde{\sigma}$ & ڤิ & 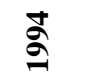 & ळ̆ & જั & $\hat{\sigma}$ & $\stackrel{2}{\sigma}$ & बे & ఫ్రి & હ્స్ & ฮ్ & ๕్ & ঙ্ণ & ஜิ & ఫ్రి & હ્స & 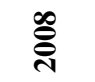 & હેస్ & 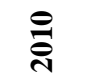 & 콕 \\
\hline \multirow{2}{*}{$\begin{array}{l}\text { Liquid } \\
\text { liabilities / } \\
\text { GDP, \% }\end{array}$} & Russia & $\ldots$ & $\ldots$ & $\ldots$ & 12.9 & 15.6 & 16.3 & 17.7 & 19.4 & 17.6 & 17.4 & 20.9 & 23.4 & 25.9 & 27.1 & 29.2 & 32.0 & 36.4 & 37.5 & 46.4 & 46.5 & 47.8 \\
\hline & China & 74.0 & 77.7 & 81.1 & 83.8 & 86.7 & 93.9 & 104.1 & 114.9 & 124.7 & 130.6 & 135.4 & 140.1 & 143.9 & 144.5 & 144.5 & 146.6 & 142.2 & 144.4 & 160.7 & 168.0 & 170.6 \\
\hline \multirow{2}{*}{$\begin{array}{l}\text { Deposit } \\
\text { money banks } \\
\text { assets / GDP, } \\
\%\end{array}$} & Russia & $\ldots$ & & & 12.3 & 15.3 & 16.8 & 19.4 & 21.3 & 19.9 & 18.5 & 21.0 & 22.8 & 24.3 & 25.4 & 26.7 & 29.5 & 34.8 & 38.6 & 48.7 & 44.9 & 45.6 \\
\hline & China & 77.6 & 76.2 & 77.0 & 76.9 & 75.3 & 80.6 & 89.2 & 100.7 & 110.3 & 114.0 & 116.4 & 121.7 & 127.5 & 126.7 & 120.8 & 114.5 & 109.5 & 110.3 & 122.6 & 130.4 & 131.6 \\
\hline \multirow{2}{*}{$\begin{array}{l}\text { Private credit } \\
\text { by deposit } \\
\text { money banks } \\
\text { / GDP, \% }\end{array}$} & Russia & $\ldots$ & $\ldots$ & $\ldots$ & 6.8 & 8.3 & 7.8 & 9.0 & 11.4 & 11.3 & 10.9 & 13.7 & 15.9 & 17.8 & 20.1 & 22.5 & 26.0 & 31.5 & 35.7 & 44.9 & 40.7 & 40.8 \\
\hline & China & 77.6 & 76.2 & 76.9 & 76.4 & 74.1 & 78.6 & 87.1 & 96.9 & 104.3 & 107.2 & 107.9 & 111.3 & 116.8 & 116.0 & 110.3 & 104.5 & 99.7 & 100.6 & 112.5 & 120.2 & 121.5 \\
\hline \multirow{2}{*}{$\begin{array}{l}\text { Bank deposits } \\
\text { / GDP, } \%\end{array}$} & Russia & $\ldots$ & & $\ldots$ & 9.3 & 11.1 & 11.5 & 12.5 & 13.5 & 12.4 & 12.5 & 15.0 & 16.8 & 18.4 & 19.0 & 20.7 & 23.4 & 27.0 & 28.1 & 35.7 & 36.3 & 37.5 \\
\hline & China & 19.6 & 21.3 & 22.1 & 22.4 & 22.2 & 23.3 & 26.4 & 29.3 & 32.4 & 36.0 & 38.2 & 41.1 & 43.7 & 44.2 & 43.3 & 42.4 & 41.9 & 41.7 & 46.6 & 50.9 & 49.9 \\
\hline \multirow{2}{*}{$\begin{array}{l}\text { Bank credits / } \\
\text { Bank } \\
\text { deposits, \% }\end{array}$} & Russia & $\ldots$ & $\ldots$ & 68.2 & 78.9 & 69.1 & 66.2 & 77.1 & 93.7 & 88.3 & 85.5 & 96.0 & 92.8 & 99.5 & 110.3 & 107.6 & 113.7 & 119.2 & 134.6 & 117.9 & 106.7 & 110.5 \\
\hline & China & 375.8 & 343.7 & 349.7 & 330.9 & 335.5 & 338.9 & 323.0 & 337.9 & 308.8 & 288.5 & 276.4 & 267.0 & 267.4 & 258.0 & 251.4 & 241.9 & 234.4 & 247.0 & 236.9 & 235.1 & 251.4 \\
\hline
\end{tabular}

Source: Financial Development and Structure Dataset (updated Nov. 2013). The World Bank, Washington DC 
Annex 2.

The composition of the commercial banking system in China

\begin{tabular}{|c|c|c|c|c|c|c|c|c|c|c|c|}
\hline & હે̊ి & 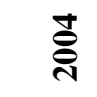 & ஜ్రి & ఫ్రి & ్ㅗㅇ & ஜ̊̊ి & ஓ્ఠ & $\stackrel{\overrightarrow{0}}{\overrightarrow{\mathrm{N}}}$ & $\overline{\bar{\sigma}}$ & $\underset{\overbrace{}}{\stackrel{N}{\sigma}}$ & $\frac{m}{\vec{\nabla}}$ \\
\hline \multicolumn{12}{|c|}{ (a) the number of commercial banks } \\
\hline «large commercial banks»* & $\cdots$ & $\ldots$ & $\ldots$ & 5 & 5 & 5 & 5 & 5 & 5 & 5 & 5 \\
\hline joint-stock commercial banks & $\cdots$ & $\ldots$ & $\cdots$ & 12 & 12 & 12 & 12 & 12 & 12 & 12 & 12 \\
\hline city commercial banks & $\cdots$ & $\cdots$ & 112 & 113 & 124 & 136 & 143 & 147 & 144 & 144 & 145 \\
\hline rural commercial banks & $\ldots$ & $\ldots$ & $\ldots$ & 13 & 17 & 22 & 43 & 85 & 212 & 337 & 468 \\
\hline foreign financial institutions $* *$ & 5 & $\ldots$ & $\ldots$ & 14 & 29 & 32 & 37 & 39 & 40 & 42 & 42 \\
\hline Postal Savings Bank of China & 0 & 0 & 0 & 1 & 1 & 1 & 1 & 1 & 1 & 1 & 1 \\
\hline Total & $\ldots$ & $\ldots$ & $\ldots$ & 158 & 188 & 208 & 241 & 289 & 414 & 541 & 673 \\
\hline \multicolumn{12}{|c|}{ (b) breakdown - in percent of total assets of the commercial banks } \\
\hline «large commercial banks»* & 73.5 & 71.8 & 70.2 & 68.6 & 66.7 & 65.1 & 63.5 & 60.6 & 58.1 & 55.0 & 52.9 \\
\hline joint-stock commercial banks & 13.6 & 14.6 & 14.9 & 15.4 & 17.0 & 17.7 & 18.4 & 19.3 & 19.9 & 21.6 & 21.7 \\
\hline city commercial banks & 6.7 & 6.8 & 6.8 & 7.3 & 7.8 & 8.3 & 8.8 & 10.1 & 10.8 & 11.3 & 12.2 \\
\hline rural commercial banks & 0.2 & 0.2 & 1.0 & 1.4 & 1.4 & 1.9 & 2.9 & 3.6 & 4.6 & 5.8 & 6.9 \\
\hline foreign financial institutions $* *$ & 1.9 & 2.3 & 2.4 & 2.6 & 2.9 & 2.7 & 2.1 & 2.3 & 2.3 & 2.2 & 2.1 \\
\hline Postal Savings Bank of China*** & 4.1 & 4.3 & 4.6 & 4.6 & 4.1 & 4.4 & 4.2 & 4.2 & 4.2 & 4.2 & 4.2 \\
\hline
\end{tabular}

(c) breakdown - in percent of the total number of employees of the commercial banks

«large commercial banks»*

joint-stock commercial banks

city commercial banks

rural commercial banks

foreign financial institutions**

Postal Savings Bank of China***

\begin{tabular}{llllllllll}
$\ldots$ & $\ldots$ & 74.4 & 77.5 & 74.7 & 71.3 & 68.5 & 66.2 & 63.2 & 60.9 \\
$\ldots$ & $\ldots$ & 6.0 & 7.3 & 8.5 & 9.4 & 10.5 & 11.3 & 12.0 & 12.9 \\
$\ldots$ & $\ldots$ & 5.8 & 6.4 & 7.6 & 8.4 & 9.2 & 9.1 & 9.8 & 9.9 \\
$\ldots$ & $\ldots$ & 1.0 & 1.5 & 1.9 & 3.1 & 4.3 & 6.3 & 8.3 & 10.1 \\
$\ldots$ & $\ldots$ & 0.8 & 1.6 & 1.4 & 1.5 & 1.6 & 1.7 & 1.7 & 1.6 \\
$\ldots$ & $\ldots$ & 12.0 & 5.7 & 5.9 & 6.3 & 5.9 & 5.4 & 5.0 & 4.7 \\
\hline
\end{tabular}

* Industrial and Commercial Bank of China, Agricultural Bank of China, Bank of China, China Construction Bank, Bank of Communications. ** Excluding foreign bank branches. *** Since 2010 the author's estimate.

Source: author's calculation based on data from: CBRC Annual Report, China Banking Regulatory Commission, Beijing, for respective years. 


\section{Annex 3.}

The number of banking entities in China and Russia

\begin{tabular}{|c|c|c|c|c|c|c|c|c|c|c|}
\hline & & ষ্ণ & ஜ̂̀ & ஓ్ & స్తి & 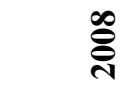 & 尺े & 를 & $\overline{\bar{d}}$ & $\frac{N}{8}$ \\
\hline \multirow{2}{*}{ Commercial banks* } & China & $\ldots$ & $\ldots$ & 144 & 170 & 185 & 198 & 204 & 201 & 203 \\
\hline & Russia & 1,249 & 1,205 & 1,143 & 1,092 & 1,058 & 1,007 & 955 & 922 & 897 \\
\hline \multirow{2}{*}{$\begin{array}{l}\text { Bank branches, excluding } \\
\text { headquarters, }\end{array}$} & China & $\cdots$ & $\cdots$ & $\cdots$ & $\ldots$ & $\cdots$ & $\cdots$ & $\cdots$ & $\ldots$ & 85,358 \\
\hline & Russia & 31,214 & 33,351 & 35,826 & 39,971 & 42,297 & 41,205 & 41,773 & 43,752 & 45,482 \\
\hline \multirow{2}{*}{$\begin{array}{l}\text { of which in } 3 \text { largest } \\
\text { cities }\end{array}$} & & $\cdots$ & $\cdots$ & $\cdots$ & $\cdots$ & $\cdots$ & $\cdots$ & $\cdots$ & $\cdots$ & 6,936 \\
\hline & Russia & $\cdots$ & $\cdots$ & $\cdots$ & $\cdots$ & $\cdots$ & $\cdots$ & 5,869 & 5,916 & 6,104 \\
\hline \multirow{2}{*}{ ATMs, } & China & $\ldots$ & $\ldots$ & 101255 & 127578 & 167489 & 214880 & 271084 & 333,789 & 415,561 \\
\hline & Russia & 19,737 & 27,779 & 39,475 & 54,804 & 79,376 & 92,530 & 156631 & 184,185 & 228,760 \\
\hline \multirow{2}{*}{$\begin{array}{l}\text { of which in } 3 \text { largest } \\
\text { cities }\end{array}$} & China & $\ldots$ & $\cdots$ & 12,832 & 16,244 & 23,044 & 27,068 & 30,238 & 36,300 & 44,823 \\
\hline & Russia & $\cdots$ & $\cdots$ & $\cdots$ & $\cdots$ & 18,468 & 20,044 & 35,586 & 38,038 & 43,216 \\
\hline \multirow{2}{*}{$\begin{array}{l}\text { Bank branches per } 1,000 \\
\mathrm{~km} 2 \text { of territory }\end{array}$} & China & $\cdots$ & $\cdots$ & $\cdots$ & $\cdots$ & $\cdots$ & $\cdots$ & $\cdots$ & $\cdots$ & $9.16^{* *}$ \\
\hline & Russia & 1.98 & 2.11 & 2.26 & 2.51 & 2.65 & 2.58 & 2.61 & 2.73 & 2.83 \\
\hline \multirow{2}{*}{$\begin{array}{l}\text { Bank branches per } 100,000 \\
\text { adults }\end{array}$} & China & $\cdots$ & $\cdots$ & $\cdots$ & $\cdots$ & $\cdots$ & $\cdots$ & $\cdots$ & $\cdots$ & $7.7 *$ \\
\hline & Russia & 26.7 & 28.5 & 30.5 & 33.9 & 35.8 & 34.9 & 35.3 & 36.8 & 38.2 \\
\hline \multirow{2}{*}{$\begin{array}{l}\text { ATMs per } 1,000 \mathrm{~km} 2 \text { of } \\
\text { territory }\end{array}$} & China & $\cdots$ & $\ldots$ & 10.9 & 13.7 & 18.0 & 23.0 & 29.1 & 35.8 & 44.6 \\
\hline & Russia & 1.2 & 1.7 & 2.4 & 3.4 & 4.9 & 5.7 & 9.6 & 11.3 & 13.5 \\
\hline \multirow{2}{*}{ ATMs per 100,000 adults } & China & $\ldots$ & $\ldots$ & 9.6 & 12.0 & 15.6 & 19.8 & 24.8 & 30.3 & 37.5 \\
\hline & Russia & 16.3 & 22.9 & 32.6 & 45.2 & 65.6 & 76.5 & 129.3 & 151.8 & 182.0 \\
\hline
\end{tabular}

* IMF figures on the number of commercial banks in China appear lower than those reported by the CBRC. **Author's calculation.

Source: Financial Access Survey, Washington DC: International Monetary Fund. http://fas.imf.org/ (last accessed in May 2014) 


\section{Annex 4.}

The average size of Chinese commercial banks

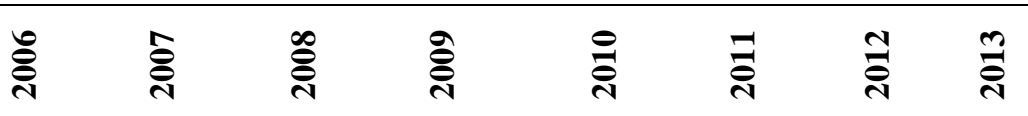

(a) the number of employees

\begin{tabular}{l|rrrrrrrr}
\hline «large commercial banks» & 293,887 & 298,428 & 296,650 & 301,285 & 309,010 & 32,245 & 333,195 & 344,141 \\
Postal Savings Bank of China* & 237,839 & 109,403 & 116,759 & 132,536 & 132,536 & 132,536 & 132,536 & 132,536 \\
joint-stock commercial banks & 9,836 & 11,662 & 13,986 & 16,471 & 19,763 & 23,171 & 26,299 & 30,342 \\
city commercial banks & 1,009 & 995 & 1,110 & 1,243 & 1,405 & 1,550 & 1,800 & 1,920 \\
foreign financial institutions** & 1,195 & 1,081 & 869 & 878 & 924 & 1,057 & 1,061 & 1,082 \\
rural commercial banks & 1,539 & 1,721 & 1,751 & 1,542 & 1,138 & 733 & 653 & 607 \\
\hline
\end{tabular}

(b) assets, RMB billion

\begin{tabular}{l|rrrrrrrr}
\hline ««large commercial banks» & 4,847 & 5,700 & 6,515 & 8,160 & 9,379 & 10,727 & 12,008 & 13,120 \\
Postal Savings Bank of China* & 1,612 & 1,769 & 2,216 & 2,705 & 3,242 & 3,853 & 4,545 & 5,148 \\
joint-stock commercial banks & 454 & 606 & 736 & 985 & 1,242 & 1,532 & 1,961 & 2,245 \\
city commercial banks & 23 & 27 & 30 & 40 & 53 & 69 & 86 & 105 \\
foreign financial institutions** & 66 & 43 & 42 & 36 & 45 & 54 & 57 & 61 \\
rural commercial banks & 39 & 36 & 42 & 43 & 33 & 20 & 19 & 18 \\
\hline
\end{tabular}

(c) assets per 1 employee, RMB million

\begin{tabular}{l|rrrrrrrr}
\hline joint-stock commercial banks & 46.1 & 52.0 & 52.6 & 59.8 & 62.8 & 66.1 & 74.6 & 74.0 \\
foreign financial institutions** & 55.5 & 40.0 & 48.4 & 41.5 & 48.4 & 50.9 & 53.4 & 56.4 \\
city commercial banks & 22.8 & 27.1 & 27.4 & 32.0 & 38.0 & 44.7 & 47.6 & 54.5 \\
Postal Savings Bank of China** & 6.8 & 16.2 & 19.0 & 20.4 & 24.5 & 29.1 & 34.3 & 38.8 \\
«large commercial banks» & 16.5 & 19.1 & 22.0 & 27.1 & 30.4 & 33.0 & 36.0 & 38.1 \\
rural commercial banks & 25.2 & 20.8 & 24.1 & 28.1 & 28.6 & 27.4 & 28.5 & 30.0 \\
\hline
\end{tabular}

* Since 2010 - the author's estimate. ** Excluding foreign bank branches.

Source: author's calculation based on data from: CBRC Annual Report, China Banking Regulatory Commission, Beijing, for respective years 


\section{Annex 5.}

Structural change in the banking systems of China and Russia

(a) China: breakdown of commercial bank total assets

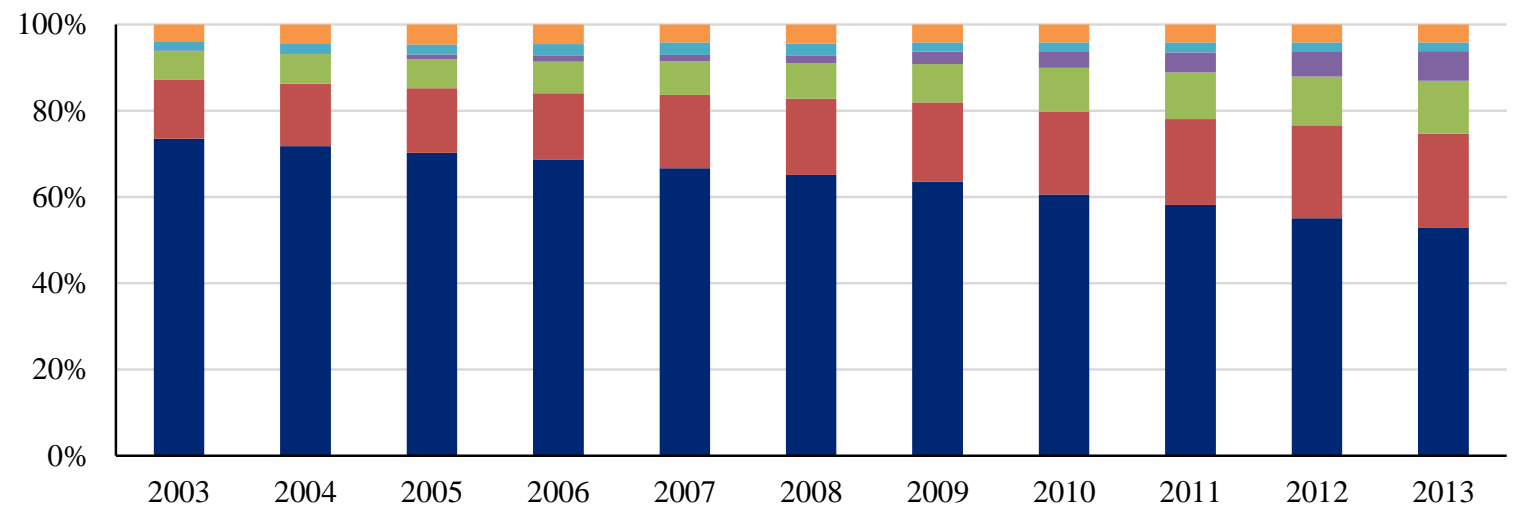

(b) China: breakdown of commercial bank total number of employees

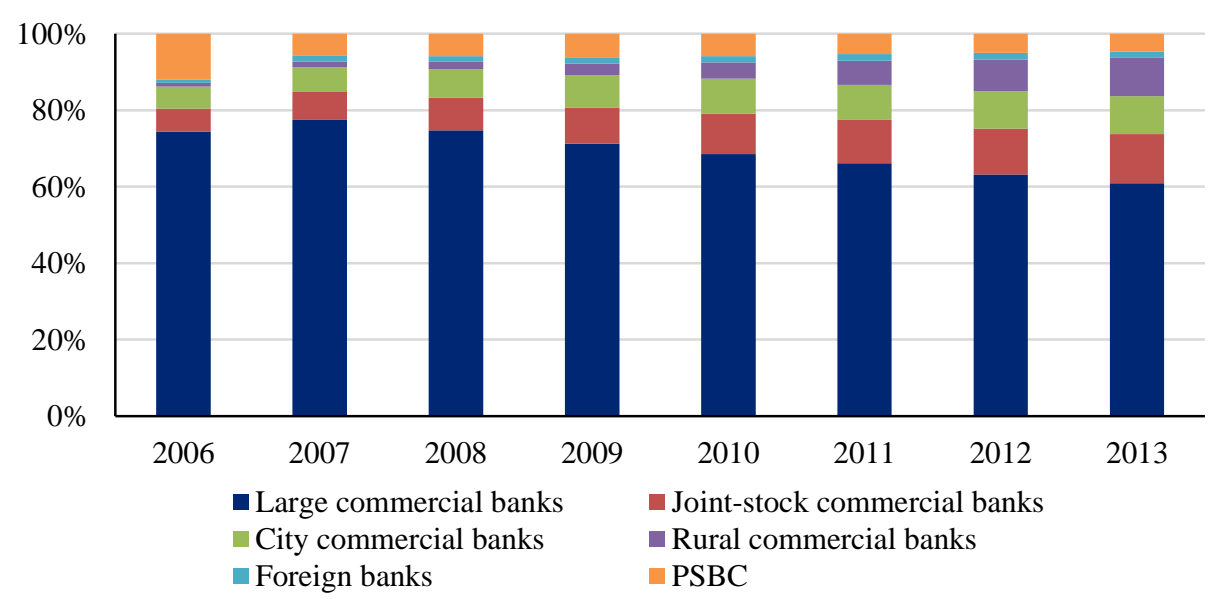

(c) Russia: breakdown of commercial bank total assets

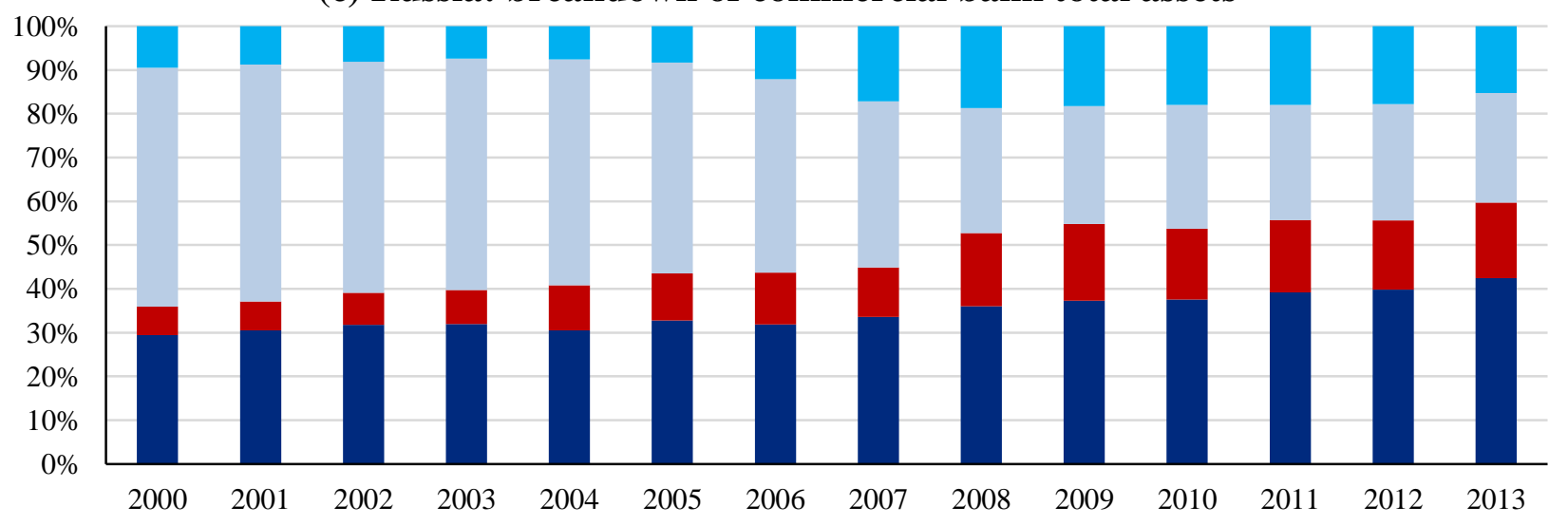

largest state-controlled banks* $\quad$ other state-controlled banks $\quad$ other banks $\quad$ foreign-controlled banks

* Sberbank, Bank VTB and Rosselkhozbank, excluding subsidiaries thereof

Source: author's calculation based on data from: CBRC Annual Report, China Banking Regulatory Commission, Beijing; CBR; RBK; RIA-Rating - for respective years. 


\section{Annex 6.}

\section{Bank efficiency in China and Russia}

\begin{tabular}{|c|c|c|c|c|c|c|c|c|c|c|c|c|c|c|c|}
\hline & & $\stackrel{\infty}{\sigma}$ & 天े & 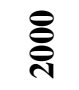 & $\overline{8}$ & 尺े & ஜ્ఠ & ষ্ণ & ஜ̊ & ஓ̊̊ి & 尺े & $\stackrel{\infty}{8}$ & $\stackrel{\hat{8}}{8}$ & $\stackrel{\theta}{\bar{\theta}}$ & ন্ \\
\hline \multirow{2}{*}{$\begin{array}{l}\text { Bank } \\
\text { overhead } \\
\text { costs / Total } \\
\text { assets, \% }\end{array}$} & China & $\ldots$ & 1.3 & 1.2 & 0.9 & 1.1 & 1.2 & 1.3 & 1.1 & 1.2 & 1.5 & 1.4 & 1.1 & 1.1 & 1.2 \\
\hline & Russia & $\ldots$ & 7.8 & 5.9 & 4.0 & 3.5 & 4.3 & 8.5 & 6.1 & 7.0 & 7.6 & 48.7 & 90.3 & 17.2 & 15.7 \\
\hline \multirow{2}{*}{$\begin{array}{l}\text { Net interest } \\
\text { margin, \% }\end{array}$} & China & $\ldots$ & 1.9 & 2.1 & 2.1 & 1.8 & 2.1 & 2.4 & 2.3 & 2.7 & 3.7 & 3.1 & 2.3 & 2.6 & 2.9 \\
\hline & Russia & $\ldots$ & 4.7 & 6.1 & 5.5 & 5.1 & 4.6 & 8.0 & 5.3 & 5.1 & 5.0 & 4.5 & 4.3 & 4.2 & 4.0 \\
\hline \multirow{2}{*}{ ROA, $\%$} & China & $\ldots$ & 0.4 & 0.3 & 0.4 & 0.4 & 0.4 & 0.4 & 0.5 & 1.0 & 1.3 & 1.0 & 1.0 & 1.1 & 0.8 \\
\hline & Russia & $\ldots$ & -1.3 & 7.4 & 2.1 & 1.3 & 1.8 & 3.4 & 2.3 & 2.3 & 2.0 & 1.1 & 0.4 & 1.1 & 1.3 \\
\hline \multirow{2}{*}{ ROE, \% } & China & $\ldots$ & 5.0 & 4.8 & 7.0 & 11.1 & 14.2 & 12.3 & 12.9 & 19.2 & 20.4 & 18.2 & 18.6 & 19.7 & 13.0 \\
\hline & Russia & $\ldots$ & 5.3 & 44.7 & 5.3 & 6.6 & 10.1 & 22.5 & 16.1 & 17.0 & 14.7 & 8.9 & 3.7 & 8.3 & 10.0 \\
\hline \multirow{2}{*}{$\begin{array}{l}\text { Cost / income } \\
\text { ratio, } \%\end{array}$} & China & 60.9 & 65.5 & 62.1 & 54.1 & 52.3 & 47.7 & 48.5 & 43.9 & 42.0 & 36.3 & 39.8 & 42.6 & 39.2 & 38.3 \\
\hline & Russia & 36.3 & 63.3 & 54.4 & 53.2 & 52.6 & 57.2 & 58.4 & 58.1 & 62.4 & 66.4 & 96.5 & 98.9 & 91.3 & 90.1 \\
\hline \multirow{2}{*}{ Z-Score } & China & $\ldots$ & 20.2 & 18.5 & 14.4 & 9.8 & 9.8 & 10.1 & 10.1 & 19.6 & 12.8 & 18.9 & 18.2 & 20.3 & 19.6 \\
\hline & Russia & $\ldots$ & 1.9 & 12.7 & 11.0 & 10.1 & 9.6 & 9.0 & 8.2 & 7.8 & 7.9 & 6.1 & 7.1 & 7.4 & 6.6 \\
\hline
\end{tabular}

Source: Financial Development and Structure Dataset (updated Nov. 2013). The World Bank, Washington $\mathrm{DC}$ 


\section{Annex 7.}

\section{Sources of investment into fixed assets}

(a) China

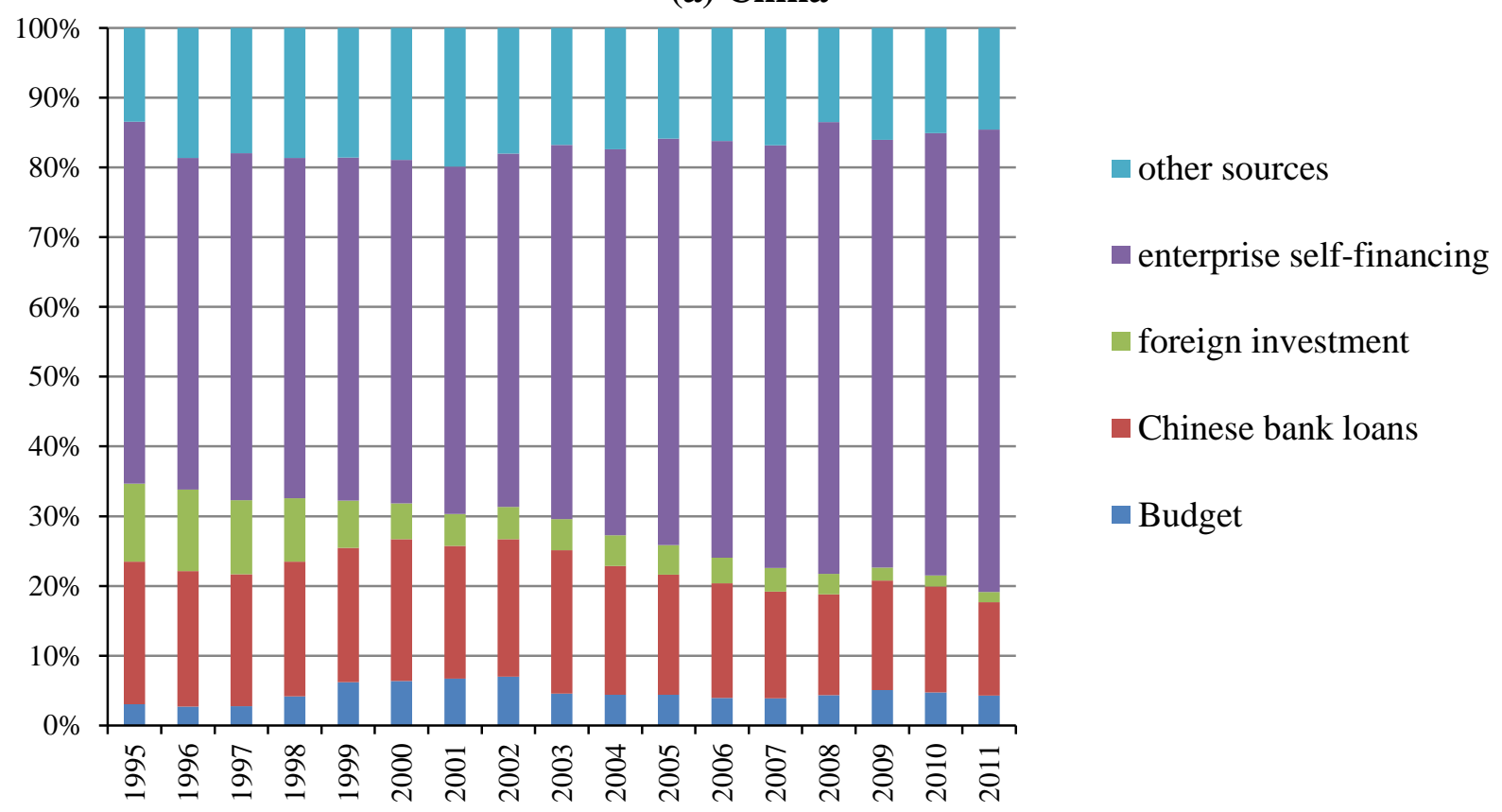

(b) Russia*

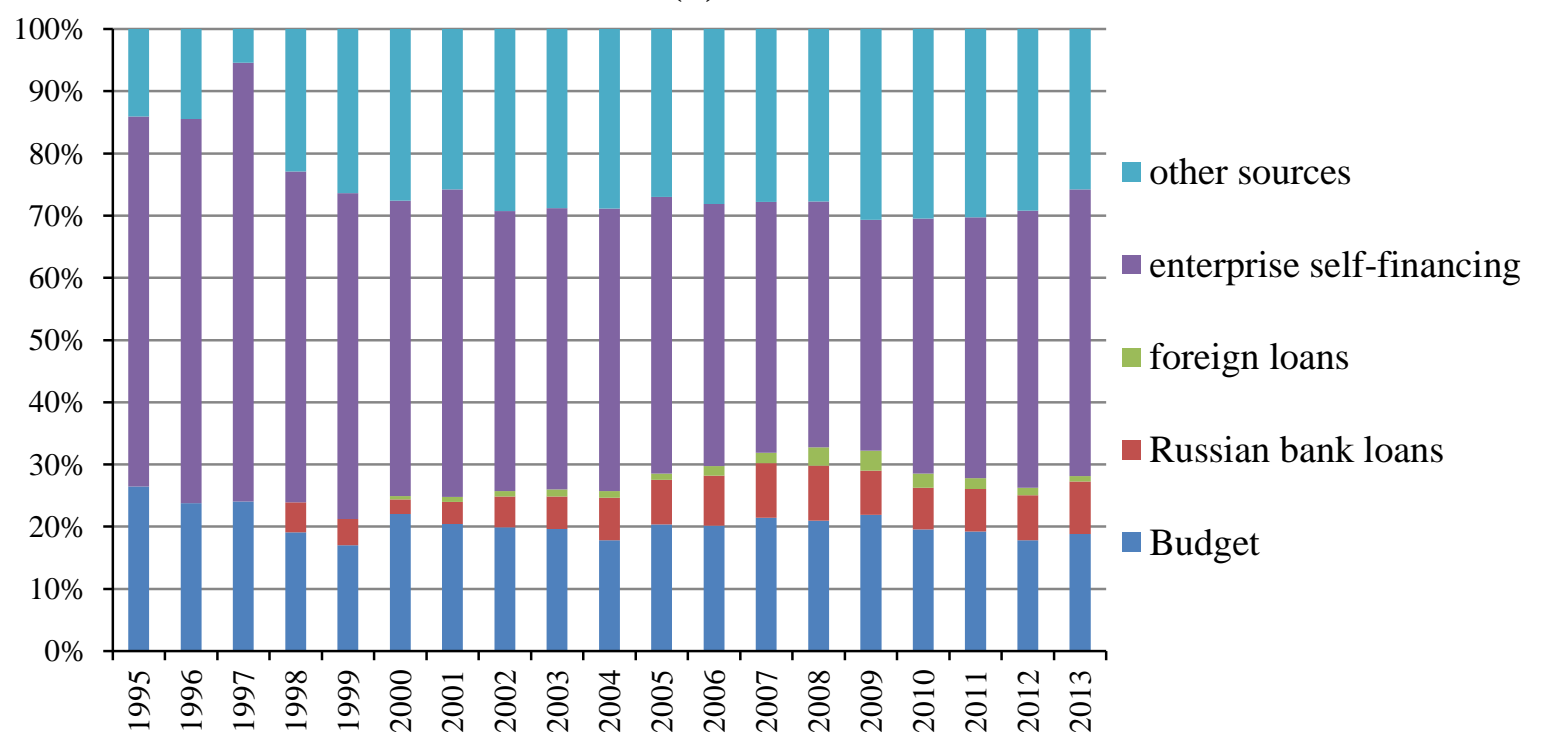

* The breakdown of investment sources into fixed assets in Russia was made compatible with the Chinese classification. 1995-1997 data on bank loans in Russia is missing.

Source: author's calculation based on data from Rosstat and National Bureau of Statistics China 


\section{Annex 8.}

Budget funds and state-controlled bank loans as sources of investment into fixed assets of nonfinancial companies (percentage of GDP)

\begin{tabular}{|c|c|c|c|c|c|c|c|c|c|c|c|c|c|c|c|}
\hline & & Еั่ & ฮิ & 气ิં & 气ิ & હ্̊ & ڤิ & ๕ั̀ & 气ิે & 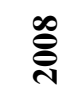 & ڤ్ & 을 & $\overline{\bar{乛}}$ & ิㅗำ & 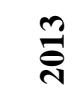 \\
\hline \multirow{2}{*}{$\begin{array}{l}\text { State budget investment } \\
\text { into fixed assets / GDP }\end{array}$} & China & 2.1 & 2.3 & 2.6 & 2.0 & 2.0 & 2.2 & 2.2 & 2.2 & 2.5 & 3.7 & 3.7 & 3.1 & $\ldots$ & .. \\
\hline & Russia & 3.2 & 3.1 & 2.7 & 2.7 & 2.4 & 2.7 & 2.9 & 3.4 & 3.4 & 3.4 & 2.8 & 2.9 & 2.8 & 2.7 \\
\hline \multirow{2}{*}{$\begin{array}{l}\text { Change in the loan } \\
\text { portfolio* of the core } \\
\text { state-controlled banks** } \\
\text { / GDP }\end{array}$} & China & 6.3 & 6.2 & 6.2 & 5.9 & 5.5 & 4.7 & 7.1 & 6.6 & 5.1 & 15.6 & 8.0 & 5.3 & 5.2 & .. \\
\hline & Russia & 1.1 & 1.6 & 1.4 & 1.8 & 1.4 & 2.1 & 1.9 & 3.5 & 3.3 & 0.4 & 1.3 & 3.0 & 1.6 & 2.4 \\
\hline \multirow{2}{*}{ Total } & China & 8.5 & 8.6 & 8.8 & 7.9 & 7.5 & 6.9 & 9.3 & 8.8 & 7.7 & 19.3 & 11.7 & 8.4 & $\ldots$ & .. \\
\hline & Russia & 4.3 & 4.6 & 4.1 & 4.5 & 3.7 & 4.8 & 4.8 & 6.9 & 6.7 & 3.8 & 4.1 & 5.9 & 4.4 & 5.1 \\
\hline
\end{tabular}

* Russia: loans to non-financial entities, China: all bank loans; ** Russia: Sberbank, Bank VTB and Rosselkhozbank; China: Industrial and Commercial Bank of China, Agricultural Bank of China, Bank of China, China Construction Bank and Bank of Communications.

Source: author's calculation based on data from Rosstat; CBR; National Bureau of Statistics China 